HANNU LAIKARI

\title{
SIMULATION OF SLUDGE BLANKET OF A VERTICAL CLARIFIER IN ACTIVATED SLUDGE PROCESS
}

Tiivistelmä

Aktiivilietepuhdistamon pystyselkeyttimen lietepatjan simulointi 
Tekijä on vastuussa julkaisun sisällöstä, eikä siihen voida vedota vesi- ja ympäristöhallituksen virallisena kannanottona.

The author is responsible for the contents of the publication. It may not be referred to as the official view or policy of the National Board of Waters and Environment.

\section{ISBN 951-47-1370-2}

ISSN 0355-0982

Helsinki 1988. Valtion painatuskeskus 


\section{CONTENTS}

$1 \quad$ Introduction 5

2 Summary of earlier investigations

2.1 On the effect of flow variations on the biological process 6

2.2 The effects of temperature on the activated sludge process 6

$\begin{array}{lll}2.3 & \text { Clarification at constant load } & 7\end{array}$

$\begin{array}{lll}\text { 2.3.1 Zone settling } & 7\end{array}$

$\begin{array}{ll}\text { 2.3.2 } & \text { Solids flux theory }\end{array}$

$\begin{array}{ll}\text { 2.3.3 Solids loss from clarifier } & 8\end{array}$

2.3.4 Dimensioning principles of the clarifier 9

2.3.5 On the development of a dynamic simulation model of thickening 9

$3 \quad$ Simulation model of sludge blanket behaviour $\quad 10$

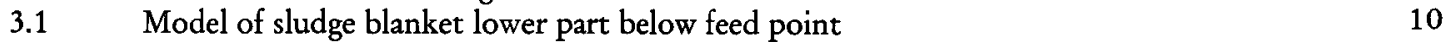

3.2 Model of sludge blanket upper part above feed point $\quad 12$

$4 \quad$ Description of tests and calculations $\quad 12$

4.1 Test plant and load rate variations used $\quad 12$

$\begin{array}{lll}4.2 & \text { Determination of sludge settling velocity } & 14\end{array}$

4.2.1 Determination of zone settling velocity by cylinder tests $\quad 14$

$\begin{array}{ll}\text { 4.2.2 Effect of depth on sludge settling velocity } & 14\end{array}$

4.2.3 Determination of settling velocity from sludge blanket steady state 15

$5 \quad$ Results of test runs $\quad 15$

5.1 Sludge blanket behaviour during load variations $\quad 15$

$5.2 \quad$ Sludge settling velocity 16

$\begin{array}{ll}\text { 5.2.1 Zone settling velocities } & 17\end{array}$

5.2.2 Depth effect on sludge settling velocity 19

$\begin{array}{ll}\text { 5.2.3 Settling velocities in steady state of clarifier } & 19\end{array}$

5.3 Effect of load variation on effluent quality from clarifier $\quad 19$

$6 \quad$ Model testing and results $\quad 20$

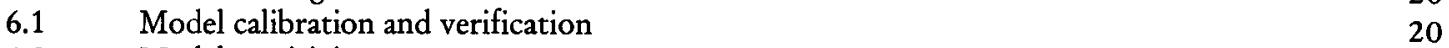

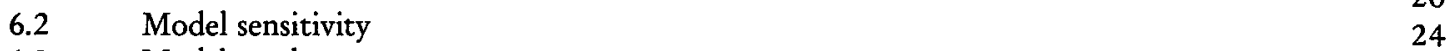

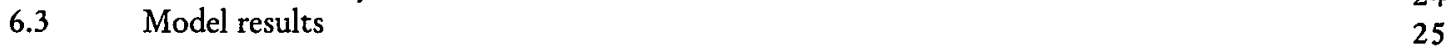

$7 \quad$ Summary of results and conclusions $\quad 30$

7.1 Modelling and experimental conditions $\quad 30$

$\begin{array}{lll}7.2 & \text { Determination of sludge settling velocity } & 30\end{array}$

$\begin{array}{lll}7.3 & \text { Clarifier efficiency and design principles } & 31\end{array}$

7.4 Proposal for further investigations

8 Summary $\quad 32$

$\begin{array}{ll}\text { Acknowledgements } & 35\end{array}$

$\begin{array}{ll}\text { Tiivistelmä } & 36\end{array}$

List of symbols $\quad 36$

$\begin{array}{ll}\text { References } & 37\end{array}$ 



\title{
SIMULATION OF THE SLUDGE BLANKET OF A VERTICAL CLARIFIER IN ACTIVATED SLUDGE PROCESS
}

\begin{abstract}
Hannu Laikari
LAIKARI, $\mathrm{H}$. 1987. Simulation of the sludge blanket of a vertical clarifier in activated sludge process. Publications of the Water Research Institute. National Board of Waters, Finland, No. 67.

This study deals with evaluation of peak loading effects from storm and snowmelt waters on the operation of a final settling unit. The load variations have been investigated using a full-scale final settling unit for which a dynamic simulation model has been developed. The model simulated profile changes in the sludge blanket caused by load variations. Furthermore, it can be used for detailed investigations into the effects of flow, solids loading, and sludge recycling on the sludge profile and clarifier capacity by varying the settling velocities within the sludge blanket. With help of the model, the dimensioning and design principles of a vertical clarifier can be further improved. In addition, a new in-situ method for the determination of sludge settling velocity has been developed, which can also take into account the influence of sludge blanket thickness on sludge settling velocity.
\end{abstract}

Index words: Activated sludge process, hydraulic loading, storm sewage, sedimentation, modelling, sludge blankets, settling characteristics.

\section{INTRODUCTION}

By the end of 1986, 610 sewage works and 578 wastewater treatment plants were operational in Finland. The majority of these were activatedsludge wastewater treatment plants with simultaneous precipitation (National Board of Waters and Environment 1987). Vertical clarifiers were used mainly in small $\left(Q<500 \mathrm{~m}^{3} \mathrm{~d}^{-1}\right)$ wastewater treatment plants. Of these, at least 200 were applied as a final settling unit, which means that every third Finnish wastewater treatment plant was provided with a vertical final clarifier.

Although the majority of sewer networks are built as separate systems, stormwaters create a problem, particularly in the months of AprilMay, that is, during the melting season of snow, as well as during sustained periods of heavy rainfall. Hence, almost two-thirds of the flows may consist of infiltration/inflow and runoff waters. These waters load the network and treatment plant capacity, increase pumping, and cause disturbances in the treatment process, especially in clarification.

The aim of this study is to evaluate load variation effects from rainfall and snowmelt waters on the operation of an activated-sludge wastewater treatment plant. In this work, the influence of load variations on the biological functions of an activated sludge plant is treated solely on the basis of information available in the current literature. 
The effects of flow variation loading of the final settling unit have been experimentally investigated using a full-scale vertical clarifier. A mathematical simulation model has been developed to describe the dynamic behaviour of the clarifier.

\section{SUMMARY OF EARLIER INVESTIGATIONS}

Relatively few studies concerning the clarification of sewage are available from the last 10 or 15 years, especially when their quantity is compared with the number of papers dealing with the microbiology of the process. Dynamic models of the biological process have been developed since the 1970's. Over the past few years, however, investigations into the clarification process have been of increased interest, particularly in the Nordic countries (Olsson 1987).

\subsection{On the effect of flow variations on the biological process}

According to published data, the microbiological process seems to be capable of bearing a flow increase of $200 \%$ at a constant substrate concentration (Wong and Yang 1977) when reactor dimensioning is based on 4,6 and 8 hour detention times. Larger increases of the flow would effect the biological activity resulting in degradation of the outflow water, however, with a quality recovery within a few hours. According to Wong and Yang, permanent changes in effluent quality were reported at a four-fold flow compared to the initial level of flow.

Their results were based on laboratory tests, whose application in full-scale activated-sludge treatment plants fails to define the characterization of such peaks that would exceed the $200 \%$ limit and yet could still provide, after a recovery period of a few hours, a satisfactory effluent quality.

\subsection{The effects of temperature on the activated sludge process}

The effect of temperature on settling is greatest with regard to individual particles. As Stokes' law states, the settling velocity of particles is dependent on viscosity. At lower temperatures, biological activity and most chemical reactions are slowed down and nitrification is inhibited. By contrast, aeration efficiency is slightly improved.

With the increase of solids concentration, the influence of temperature on the functions of the settling tank sludge blanket decreases already at a concentration level of $3 . .4 \mathrm{~g} \mathrm{l}^{-1}$ (Tesarik and Vostril 1970). In addition, the decrease of temperature has been estimated to reduce sludge flocculation by decreased production of biopolymers, and consequently, the settling of sludge (i.a. Särner and Marklund 1982).

According to Hernebring (1984), a temperature decrease, e.g., from $20^{\circ} \mathrm{C}$ to $10^{\circ} \mathrm{C}$ at the Boden wastewater treatment plant, corresponded approximately to a three-fold flow in terms of $\mathrm{BOD}_{7}$ reduction (Fig. 1).

Low temperatures are encountered at treatment plants especially in the spring when the flow is highest. With the increase of sludge generation, keeping the sludge age sufficiently high and sludge loading sufficiently low, presupposes an increase of the aeration tank sludge concentration, which would dictate larger final clarifiers than are customarily found today (Mäkelä 1981).

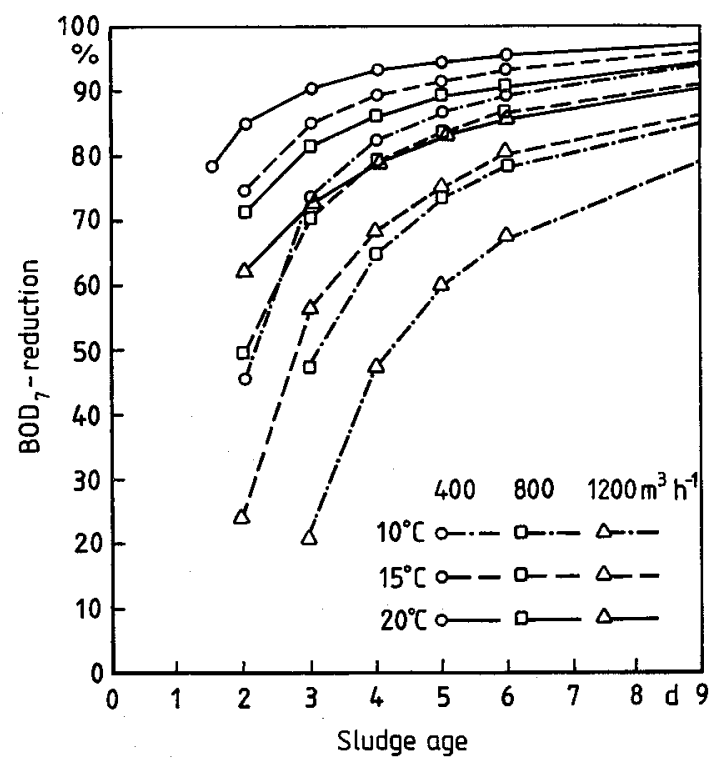

Fig. 1. $\mathrm{BOD}_{7}$ reduction as a function of sludge age at a varying hydraulic load and temperature (Hernebring 1984). 


\subsection{Clarification at constant load}

The dimensioning of a clarifier is generally based on a constant load. In addition to clarification, the settling tank performs sludge thickening.

A prerequisite of acceptable clarification is flocculation of particles, which further presupposes adequate sludge age, or "maturity" of microbiological growth. Fibrous strands and film networks, i.e. biopolymers, are important, although the particular mechanisms involved are not fully understood (Gaudy and Gaudy 1980).

Several researchers have investigated the effect of sludge age on the settling behaviour of sludge. Regarding the results, it can be noted that the portion of nonflocculated particles in sludges with an age less than $2 \mathrm{~d}$ increased. Equally, the zone settling velocity (settling velocity of sludge blanket surface) increased in the tests for sludges with an age in excess of $3 \mathrm{~d}$, while low values of sludge volume index (SVI) were found for sludges with $t_{s}<2 d$ and $t_{s}>5 d$ (Bisogni and Lawrence 1971, and Chao and Keinath 1979) (Fig. 2).

A high level of sludge loading

$\left(>0.5 \mathrm{~g} \mathrm{BOD}_{5} \mathrm{~d}^{-1} \mathrm{MLSS}^{-1}\right)$ and a low sludge age inhibit the formation of a solid floc, while a low sludge load promotes bioflocculation (Task Committee on Final Clarification 1979).

The questions of whether and to what degree the results from autoflocculation are applicable to a simultaneous precipitation process, remains unsettled because a fast hydrolysis reaction is induced by, e.g., the hydrolysis products of aluminium and ferrous salts, with the reaction products being able to form bridging between the cells thus advancing flocculation.

\subsubsection{Zone settling}

The zone settling velocity, or the settling velocity of the water-to-sludge interface, is based on the theory proposed by Kynch (1952), according to which the velocity is dependent only on the solids concentration of the suspension until all sludge particles are mechanically interacting with each other. This settling velocity is generally determined by performing a batch test in a glass cylinder or similar vessel ("jar test"), and it has also been used to describe sludge settling velocity within the sludge blanket (Fig. 3). Zone formation presupposes a certain minimum concentration $\left(0.5 \mathrm{~g}^{-1}\right)$. Elimination of the wall effect dictates a sufficient cylinder diameter $(100 \times$ floc diameter, according to Tesarik and Vostril 1970). To take into account the sludge blanket depth, the determination of
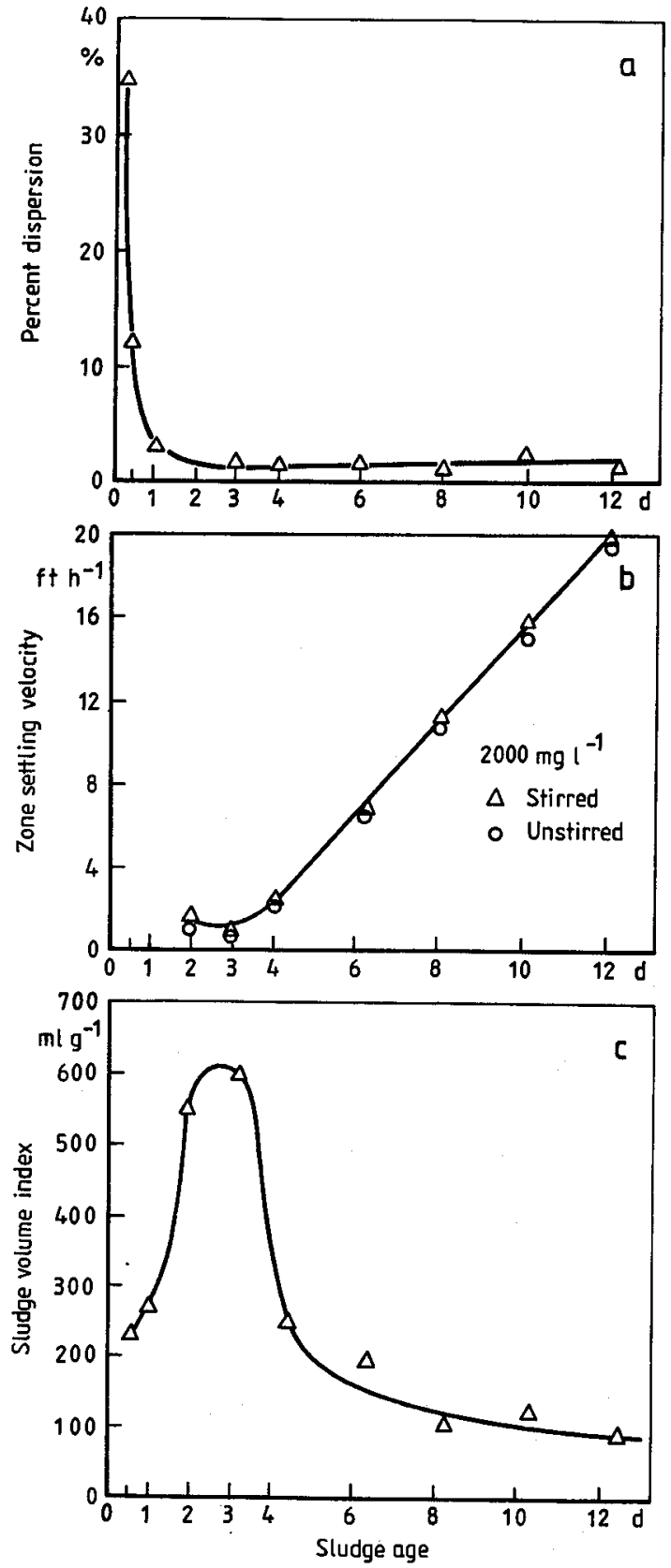

Fig. 2. a) Proportion of nonflocculated cells as a function of sludge age. b) Zone settling velocity as a function of sludge age. c) Sludge volume index as a function of sludge age (Bisogni and Lawrence 1971).

velocity should be performed at different depths (Dick and Eving 1967, Dick 1972), although the importance of depth in conjunction with highquality sludges would not be recognizable. 

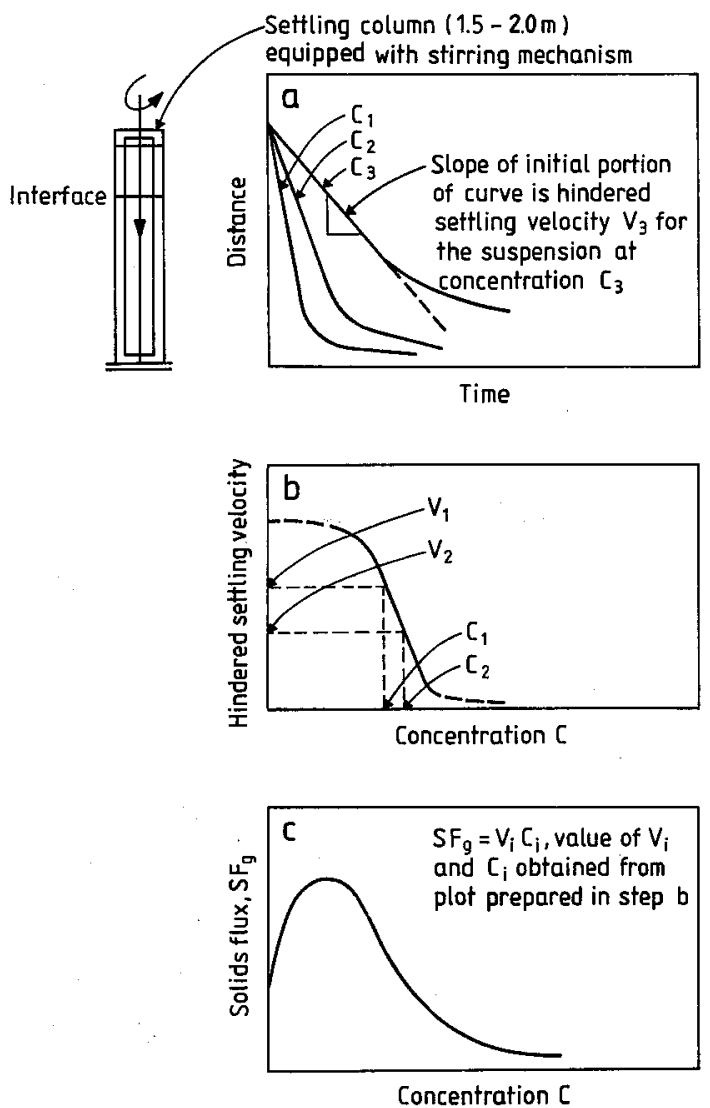

Fig. 3. Method for determining the graph of gravity induced solids flux as a function of solids concentration. a) Settling velocity derived from settling tests for different concentrations. b) Settling velocity test values from graph a) plotted as a function of concentration. c) Solids flux calculated values as a function of concentration (Metcalf \& Eddy, Inc. 1979).

The importance of temperature and sludge age to the zone settling velocity has been investigated by several researchers, who have determined the empirical relationships between these variables (i.a. Vasiliev and Vavlin 1982, Roper and Grady 1974, Bisogni and Lawrence 1971, and Tesarik and Vostril 1970). Generalization of the results indicates that an increasing concentration diminishes the effect of sludge age and temperature to the settling velocity. According to Dick and Eving (1967), also the particle size and settling velocity increase at increasing depth. In addition, the quality of sludge has an appreciable effect on the thickening of sludge (Lockyear 1978).

In summary, it can be inferred from earlier studies that at lower concentrations (at about $2 . .5 \mathrm{~g} \mathrm{l}^{-1}$, e.g., in the upper part of the vertical clarifier), the temperature, sludge age, and depth of the sludge blanket affect the sludge settling velocity. Deeper in the clarifier, where the sludge concentration exceeds a level of about $4 . .5 \mathrm{~g} \mathrm{l}^{-1}$, sludge particles come into contact with each other, and the settling velocity diminishes appreciably. Sludge quality is the second most important factor to sludge thickening.

\subsubsection{Solids flux theory}

The limiting solids flux theory proposed by Dick (1970) is almost unanimously accepted in general use in, e.g., textbooks. According to this theory, the solids inflow to the clarifier may not exceed the permeability of any layer of the sludge blanket in order to avoid sludge from accumulating in the clarifier and hence raising the level of sludge blanket surface. Thus, the tank or basin area must be sufficiently large relative to the solids inflow and to sludge removal from the bottom of the tank. A limiting solids flux has been determined by batch tests from the zone settling velocities and the corresponding concentrations (Metcalf $\&$ Eddy, Inc. 1979) (Fig. 4). The validity and applicability of Dick's theory has been questioned by, for instance, Vasiliev and Vavlin (1982), who preferably limit the applications of the theory to ideal cases.

\subsubsection{Solids loss from clarifier}

Several researchers (i.a. Pflanz 1969, Roper and Grady 1974, Busby and Andrews 1975, Keinath et al. 1977, Collins et al. 1978, and Chobrial 1978) have created models in order to calculate solids concentration in the effluent water of the clarifier.

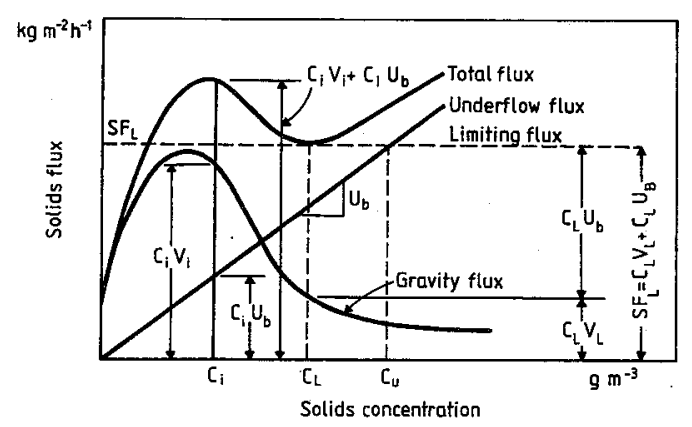

Fig. 4. Graphic presentation of solids flux method (Metcalf \& Eddy, Inc. 1979). 
The models take into account the effect of the different variables, such as influent solids, recycle ratio, temperature, sludge age, and sludge blanket level to the solids concentration in the effluent water.

Load variation experiments performed at fullscale plants (i.a. Munch and FitzPatrick 1978, Särner and Marklund 1981 and 1982, and Hernebring 1984) indicate that solids loss from the clarifier is the principal degrading factor of the process, and thus the important parameters are the sludge blanket level, sludge settling velocity and the absolute hydraulic load (hydraulic surface load), mutual relation between hydraulic and sludge load, shock loading, and low temperature. According to Hernebring, control operations applied are capable of reducing the $\mathrm{BOD}_{7}$ of effluent water to a remarkable extent.

\subsubsection{Dimensioning principles of the clarifier}

With reference to Metcalf \& Eddy, Inc. (1979), the surface load rate should be dimensioned according to the peak flow of the clarifier. Otherwise, appreciable quantities of solids might escape with the effluent. Typical design values of the surface load rates are $0.7 \ldots 1.3 \mathrm{~m}^{3} \mathrm{~m}^{-2} \mathrm{~h}^{-1}$ for the average load and $1.8 \ldots 2.0 \mathrm{~m}^{3} \mathrm{~m}^{-2} \mathrm{~h}^{-1}$ for peaks. The solids load rate should be estimated according to both the peak flow and the average flow. If the flow peaks are short, the 24-hour average can be used; otherwise the peak values are applied. Quality degradation of the effluent water has been recorded in a clarifier with a certain area if the solids flow increases above the design value. Typical sludge surface load rates quoted in the literature are in the range of $3.0 \ldots 6.0 \mathrm{~kg} \mathrm{~m}^{-2} \mathrm{~h}^{-1}$. Higher values should not be applied without settling tests. Even then the tests should be performed during different times of the year and at different alternatives of operating parameters. It is suggested that the maximum surface load rated be limited to $9.0 \mathrm{~kg} \mathrm{~m}^{-2} \mathrm{~h}^{-1}$.

Because the area required for thickening is generally larger than that needed for settling, thickening is typically the dominating factor. For removal of scattered particles, settling may require additional area or a minimum detention $(2 \mathrm{~h})$ for extended flocculation.

In USA, the surface load has lately been extensively compensated for by taking into account the wall height of the basin as well as the sludge storage. A height of $3.5 .15 \mathrm{~m}$ is suggested in literature by Metcalf \& Eddy, Inc. (1979) for the basin depth.
Aeration and the settling basin are functionally dependent on each other via the solids concentration in the aeration basin and the return sludge concentration in settling. A high sludge concentration in the aeration basin increases the cost and size of the clarifier while the same factors for the aeration basin decrease, and vice versa for a lower sludge concentration in aeration (Dick 1976 and Task Committee on Final Clarification 1979).

In Finland, the guidelines published by the National Board of Waters suggest that the clarifier be dimensioned according to the surface load the sludge volume load, which lead to area selection on the basis of guideline values. Depending on the clarifier type and its operation, surface load rates in the range of $0.5 \ldots 1.5 \mathrm{~m}^{3} \mathrm{~m}^{-2} \mathrm{~h}^{-1}$ are recommended. In order to achieve efficient clarification in the vertical final settling unit (Fig. 5), the recommended load rate level is given as $0.9 \mathrm{~m}^{3} \mathrm{~m}^{-2}$ $\mathrm{h}^{-1}$ and the maximum limit should set as $1.4 \mathrm{~m}^{3}$ $\mathrm{m}^{-2} \mathrm{~h}^{-1}$. Recommended surface load rate is given as $1.2 \mathrm{~m}^{3} \mathrm{~m}^{-2} \mathrm{~h}^{-1}$. In addition, values for the height of the vertical wall in the basin and the bottom slope are given, as well as on the sludge load, sludge concentration, and sludge index selection (Table 1).

\subsubsection{On the development of a dynamic simulation model of thickening}

Dynamic models of thickening are based on the solids flux theory proposed by Dick (1970), which is based on the principle that the total solids flux at any point of the clarifier is the sum of the settling flux caused by gravitation and the flow caused by the return sludge pumping (Fig. 4). The model has been further developed by several researchers (e.g. Talmadge and Fitch 1955, Dick

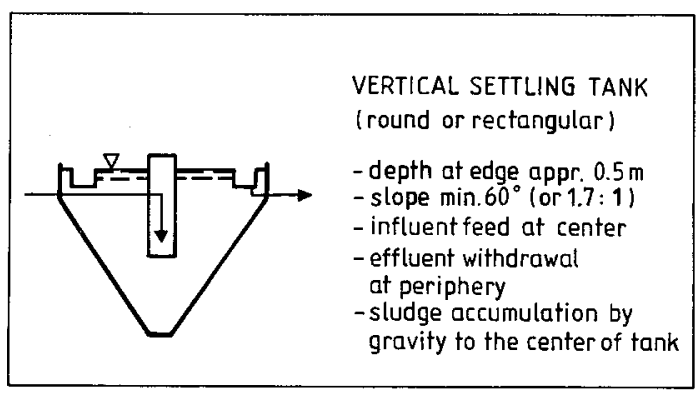

Fig. 5. Dimensioning guidelines of a vertical clarifier (National Board of Waters 1982, according to a publication by the Association of Finnish Cities 1980). 
Table 1. Guidelines for surface load rates and wall heights of basins (National Board of Waters 1982).

\begin{tabular}{|c|c|c|c|c|c|}
\hline \multirow[t]{2}{*}{ Function } & \multirow[t]{2}{*}{ Basin type } & \multirow[t]{2}{*}{$\begin{array}{c}\text { Wall } \\
\text { height } \\
(\mathrm{m})\end{array}$} & \multicolumn{3}{|c|}{$\begin{array}{c}\text { Surface } \\
\text { load rate } \\
\left(\mathrm{m}^{3} \mathrm{~m}^{-2} \mathrm{~h}^{-1}\right)\end{array}$} \\
\hline & & & A & B & C \\
\hline $\begin{array}{l}\text { Final settling } \\
\text { in activated } \\
\text { sludge or } \\
\text { postprecip- } \\
\text { itation } \\
\text { process }\end{array}$ & $\begin{array}{l}\text { Shallow } \\
\text { rectangular } \\
\text { Deep rectangular } \\
\text { Shallow round } \\
\text { Deep round } \\
\text { Vertical } \\
\text { settling }\end{array}$ & $\begin{array}{l}2.5 \\
3.5 \\
2.5 \\
3.5\end{array}$ & $\begin{array}{l}0.6 \\
0.8 \\
0.5 \\
0.7 \\
0.9\end{array}$ & $\begin{array}{l}0.7 \\
1.0 \\
0.6 \\
0.8 \\
\\
1.2\end{array}$ & $\begin{array}{l}0.9 \\
1.2 \\
0.8 \\
1.0\end{array}$ \\
\hline
\end{tabular}

$\mathrm{A}=$ Efficient settling result (e.g. $\mathrm{P}<1 \mathrm{mg} \mathrm{l}^{-1}$ ) in simultaneous precipitation

$\mathrm{B}=$ Recommended rate, not to be exceeded without justified arguments (e.g. precipitation with lime)

$\mathrm{C}=$ Maximum limit

and Eving 1967), who consider the batch test to be applicable for determining the sludge settling velocity and further see the model to be sufficiently reliable for satisfactory results.

In order to simplify the models and improve simulation, certain assumptions are made in their development. In the model of Tracy and Keinath (1973), the clarifier is divided into 10 layers, whose material rate equations are formed into a set of computational equations. Each layer is handled as a fully mixed reactor, and computation is carried out in a series by layers. Computational corrections are done by altering the layer thickness. The model has been developed for a clarifier in which the activated sludge is falling onto the sludge blanket, that is, the feed point is always above the top level of the sludge blanket.

Simulation of a clarifier with sludge feed into the interior of the sludge blanket, that is, the blanket surface lying in principle above the feed point, is not presented in literature. In this case, the solids floating or settling in an upward flow is influenced in addition to gravity, also by the upward flow and a vorticous turbulence, whose presence is estimated by, for instance, Tesarik and Vostril (1970), to decrease the settling velocity by $9 \%$. Thus, the lower part of the blanket below the feed point requires a different model compared to that of the part above the feed point. The distribution of fed solids between the upper section and lower section relative to the feed point is superficially mentioned by Tracy and Keinath (1973) to be determined by the differences between the solids fluxes of the influent and the limiting flux (Fig. 4).

\section{SIMULATION MODEL OF SLUDGE BLANKET BEHAVIOUR}

The model simulating the operation of the sludge blanket consists of two parts: a model for the lower part of the blanket below the influent feed point, which is a modified version of the model described in the literature referenced in the foregoing, and a new model for the upper part of the blanket above the feed point including its functional relationships with the lower part, which has been developed in this study.

\subsection{Model of sludge blanket lower part below feed point}

In the study, an improved mathematical model of sludge thickening in the final clarifier of a test plant was formulated from the model proposed by Tracy and Keinath (1973). The model by Tracy and Keinath describes continual thickening of sludge in such circumstances whereby the orifice of the influent feed pipe of activated sludge in the clarifier is located above the sludge blanket top level. Equations formulated by Tracy and Keinath for a cylinder-shaped clarifier are modified so that the constant cross-section of the tank is taken as a variable function of the vertical coordinate.

Volume $V_{i}$ accumulates the difference of material quantity (that is, the solids flux) entering the volume through surface $A_{i+1}$, and exiting the volume through surface $A_{i}$ (Fig. 6a).

$V_{i} \frac{d C_{i}}{d t}=A_{i+1} G_{i+1}-A_{i} G_{i}$

The solids flux $\mathrm{G}$ (from equation 2) and underflow velocity of sludge $u$ (from equation 3) are substituted in equation (1)

$\mathrm{G}_{\mathrm{i}}=\mathrm{C}_{\mathrm{i}}\left(\mathrm{v}_{\mathrm{i}}+\mathrm{u}_{\mathrm{i}}\right) ; \mathrm{G}_{\mathrm{i}+1}=\mathrm{C}_{\mathrm{i}+1}\left(\mathrm{v}_{\mathrm{i}+1}+\mathrm{u}_{\mathrm{i}+1}\right)$

$u_{i}=\left(Q_{R}+Q_{W}\right) / A_{i} ; u_{i+1}=\left(Q_{R}+Q_{W}\right) / A_{i+1}$

and by dividing equation (1) by volume $\left(V_{i}\right)$, sludge concentration change in the clarifier is given as a function of time and position:

$\frac{\mathrm{dC}_{\mathrm{i}}}{\mathrm{dt}}=\frac{\mathrm{A}_{\mathrm{i}+1}}{\mathrm{~V}_{\mathrm{i}}} \mathrm{C}_{\mathrm{i}+1} \mathrm{v}_{\mathrm{i}+1}+\mathrm{C}_{\mathrm{i}+1} \frac{\mathrm{Q}_{\mathrm{R}}+\mathrm{Q}_{\mathrm{w}}}{\mathrm{V}_{\mathrm{i}}}+$

$-\left[\frac{\mathrm{A}_{\mathrm{i}}}{\mathrm{V}_{\mathrm{i}}} \mathrm{C}_{\mathrm{i}} \mathrm{v}_{\mathrm{i}}+\mathrm{C}_{\mathrm{i}} \frac{\mathrm{Q}_{\mathrm{R}}+\mathrm{Q}_{\mathrm{w}}}{\mathrm{V}_{\mathrm{i}}}\right]$ 


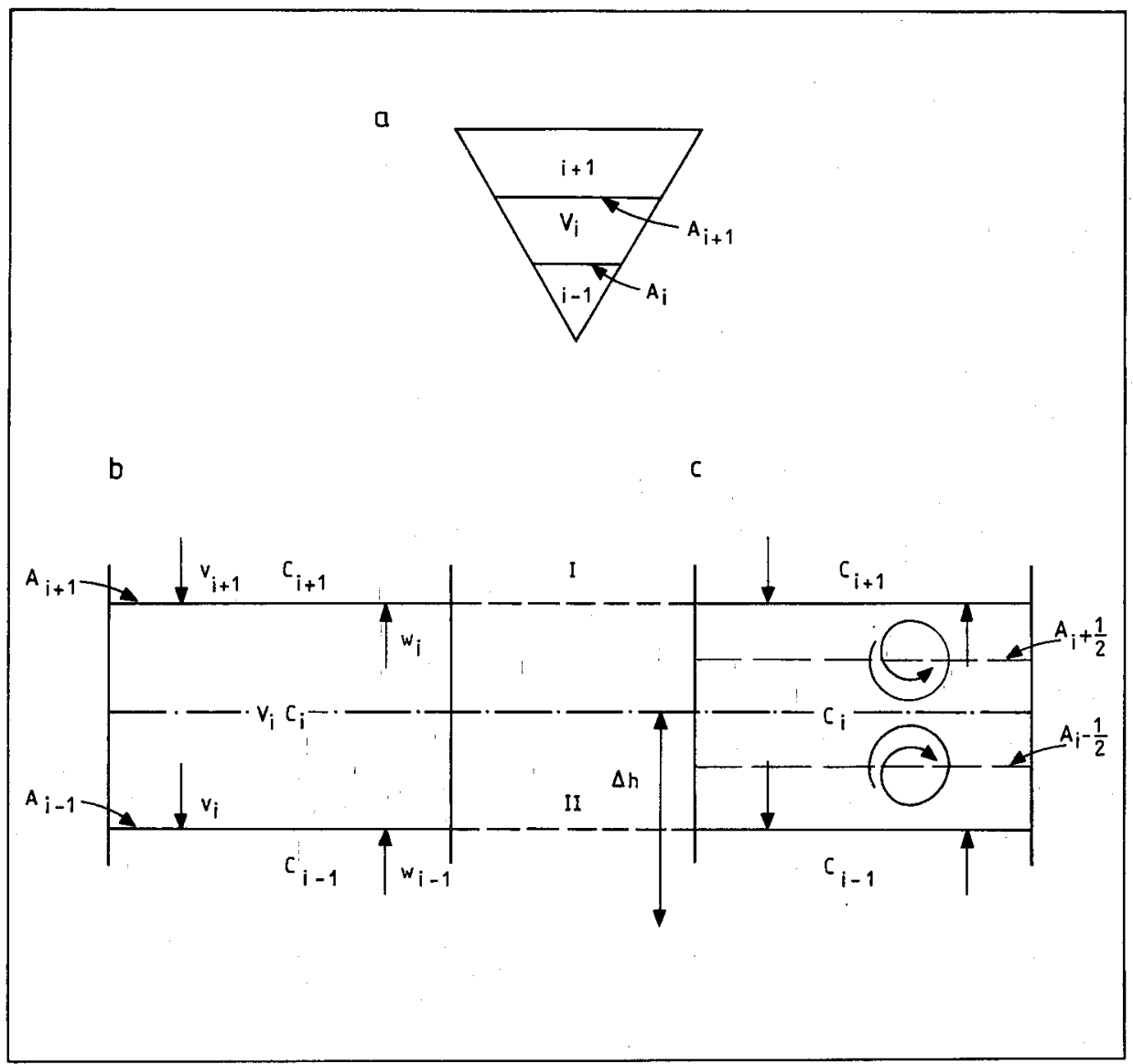

$\mathrm{V}_{\mathrm{i}} \quad=$ layer $\mathrm{i}$ volume

$\mathrm{A}_{\mathrm{i}}=$ interface between layers $\mathrm{i}$ and $\mathrm{i}-1$

$A_{i+1}=$ interface between layers $i$ and $i+1$

$\mathrm{v}_{\mathrm{i}} \quad=$ velocity due to gravity in layer $\mathrm{i}$

$\mathbf{w}_{i}=$ liquid flow velocity in layer $\mathrm{i}$ due to withdrawal of clarified water

$\mathrm{C}_{\mathrm{i}}=$ solids concentration in layer $\mathrm{i}$

$\mathrm{D}=$ diffusion coefficient

$\Delta \mathrm{h}=$ layer thickness

Fig. 6. Model of sludge blanket thickening and symbol conventions in a vertical clarifier. a) Model shape and symbols below feed point. b) Schematic diagram of flow components above feed point. c) Schematic diagram of vorticous mixing above feed point.

The solids balance of the clarifier bottom layer (i-1) differs from the balances of intermediate layers because the velocity component due to gravity in equation (4) is zero:

$\frac{\mathrm{dC}_{\mathrm{i}}}{\mathrm{dt}}=\frac{\mathrm{A}_{\mathrm{i}+1}}{\mathrm{~V}_{\mathrm{i}}} \mathrm{C}_{\mathrm{i}+1} \mathrm{v}_{\mathrm{i}+1}+\mathrm{C}_{\mathrm{i}+1} \frac{\mathrm{Q}_{\mathrm{R}}+\mathrm{Q}_{\mathrm{w}}}{\mathrm{V}_{\mathrm{i}}}$

$-C_{i} \frac{Q_{R}+Q_{w}}{V_{i}}$
When the sludge blanket level is at the feed point level, in equation (1) is $A_{i+1} G_{i+1}=Q_{0} C_{0}-Q_{E} C_{E}$, which is equal to the solids flux underflow from the clarifier bottom. Then, the equation can be written as:

$$
\begin{aligned}
& \frac{\mathrm{dC}_{\mathrm{i}}}{\mathrm{dt}}=\left(\mathrm{Q}_{0} \mathrm{C}_{0}-\mathrm{Q}_{\mathrm{E}} \mathrm{C}_{\mathrm{E}}\right) / \mathrm{V}_{\mathrm{i}} \\
& -\left[\frac{\mathrm{A}_{\mathrm{i}}}{\mathrm{V}_{\mathrm{i}}} \mathrm{C}_{\mathrm{i}} \mathrm{v}_{\mathrm{i}}+\frac{\mathrm{Q}_{\mathrm{R}}+\mathrm{Q}_{\mathrm{w}}}{\mathrm{V}_{\mathrm{i}}}\right]
\end{aligned}
$$


In literature (Busby and Andrews 1975), equations (1)...(6) are earlier solved by computing only one layer per iteration cycle using the Runge-Kutta method, and the other layers are extrapolated using the original concentration distribution. This method has proved to be inaccurate. In this study, a satisfactory result has been achieved by increasing the number of layers and solving the equations by a successive method layer by layer.

The sludge blanket of the clarifier lower part can maximally handle the limiting solids flux. Any part of the load exceeding the limiting flux is built up to the upper part of the clarifier above the feed point. The limiting solids flux and the corresponding limiting concentration $\left(\mathrm{C}_{\mathrm{L}}\right)$ are obtained by determining the minimum value of solids flux.

$\mathrm{G}_{\mathrm{i}}=\mathrm{C}_{\mathrm{i}} \mathrm{v}_{\mathrm{i}}+\mathrm{C}_{\mathrm{i}} \mathrm{u}(\mathrm{h})$

where

$\mathrm{u}(\mathrm{h})=\left(\mathrm{Q}_{\mathrm{R}}+\mathrm{QW}_{\mathrm{W}}\right) / \mathrm{A}(\mathrm{h}) ; \mathrm{v}_{\mathrm{i}}=\mathrm{k}_{1} \mathrm{C}_{\mathrm{i}}^{-\mathrm{k}_{2}}$

$\mathrm{G}_{\mathrm{i}}=\mathrm{C}_{\mathrm{i}} \mathrm{k}_{\mathrm{i}} \mathrm{C}_{\mathrm{i}}^{-\mathrm{k}_{2}}+\mathrm{C}_{\mathrm{i}}\left(\mathrm{Q}_{\mathrm{R}}+\mathrm{Q}_{\mathrm{W}}\right) / \mathrm{A}(\mathrm{h})$

$\frac{\partial G_{i}}{\partial C_{i}}=k_{1}\left(1-k_{2}\right) C_{i}^{-k_{2}}+\left(Q_{R}+Q_{W}\right) / A(h)=0$

and when

$\mathrm{C}=\mathrm{C}_{\mathrm{L}}$
$\mathrm{C}_{\mathrm{L}}=\left[\frac{\mathrm{k}_{1}\left(\mathrm{k}_{2}-1\right) \mathrm{A}(\mathrm{h})}{\mathrm{Q}_{\mathrm{R}}+\mathrm{QW}_{\mathrm{W}}}\right]^{1 / \mathrm{k}_{2}}$

\subsection{Model of sludge blanket upper part above feed point}

When the sludge blanket top level is above the feed point, the sludge thickening model is based on the difference between the downward flux due to gravity and the upwards flow of solids flux in the clarifier (Fig. 6b).

The upwards flow causes vorticous mixing around a settling sludge particle which reduces the settling velocity of the particle (Fig. 6c). The concentration change per time unit in a volume unit $\left(V_{i}\right)$ under study, or build-up of solids, is equal to the difference between inflow and outflow solids flux to the space reduced by the solids mass difference caused by the vorticous mixing between the inflow and outflow.

$$
\begin{aligned}
\mathrm{V}_{\mathrm{i}} \frac{\mathrm{dC_{i }}}{\mathrm{dt}}= & \left(w_{i-1} C_{i-1} A_{i-1}-w_{i} C_{i} A_{i+1}\right) \\
& +\left(v_{i+1} C_{i+1} A_{i+1}-v_{i} C_{i} A_{i-1}\right) \\
& -\left(\left(A_{i-1 / 2} D_{i-1 / 2} \frac{C_{i-1}-C_{i}}{\Delta h}\right.\right. \\
& \left.-A_{i+1 / 2} D_{i+1 / 2} \frac{C_{i}-C_{i+1}}{\Delta h}\right)
\end{aligned}
$$

When the equation is divided by $V_{i}$, and limits $\mathrm{I}$ and II are allowed to approach each other (Fig. 6c), it can be written as:

$\begin{array}{ll}\mathrm{v}_{\mathrm{i}}=\mathrm{dz} \times \mathrm{A}_{\mathrm{i}} & \mathrm{A}_{\mathrm{i}-1}=\mathrm{A}_{\mathrm{i}}=\mathrm{A}_{\mathrm{i}+1} \\ \mathrm{v}_{\mathrm{i}}=\mathrm{v}_{\mathrm{i}+1} & \mathrm{C}_{\mathrm{i}-1}-\mathrm{C}_{\mathrm{i}}=\mathrm{C}_{\mathrm{i}}-\mathrm{C}_{\mathrm{i}+1}=\mathrm{dC} \\ \mathrm{w}_{\mathrm{i}}=\mathrm{w}_{\mathrm{i}+1} & \Delta \mathrm{h}=\mathrm{dz}\end{array}$

and equation (11) can further be written as:

$\frac{\partial \mathrm{C}}{\partial \mathrm{t}}=\frac{\partial(\mathrm{wC})}{\partial \mathrm{z}}+\frac{\partial(\mathrm{vC})}{\partial \mathrm{z}}-\frac{\partial \mathrm{D}}{\partial \mathrm{z}}\left(\frac{\partial \mathrm{C}}{\partial \mathrm{z}}\right)$

The numerical solution of equation (12) is performed by approximating the equation by equation (11) and assuming variables $V_{i}, A_{i-1}, A_{i}$, $A_{i+1}, w_{i}, w_{i+1}, v_{i-1}$, and $v_{i+1}$ to be constants so that furthermore $v_{i-1}=v_{i}=v_{i+1}$.

If the value of $\Delta h$ is sufficiently small, the computational error is also small because, according to observations, $\mathrm{C}$ is approximately constant in the layer (above the feed point). The numerical solution is implemented using the ChevereauPreissimann algorithm. The diffusion coefficient is (Shiba and Inone 1975):

$\mathrm{D}=\mathrm{K}_{3}(w d)^{\mathrm{k}_{4}}$

Where $\mathrm{w}$ is the velocity in the upwards direction, $\mathrm{d}$ the hydraulic diameter of the clarifier, and coefficients $\mathrm{k}_{3}$ and $\mathrm{k}_{4}$ are constants.

\section{DESCRIPTION OF TESTS AND CALCULATIONS}

\subsection{Test plant and load rate variations used}

The test runs of the study were performed at a test plant constructed at the Suomenoja central wastewater treatment plant of Espoo City. The central treatment plant treats a domestic wastewater load of about 100000 inhabitants. An 
activated sludge system with simultaneous precipitation was operated at the test plant. Sewage to the test plant was pumped from the inflow sewer of the central treatment plant. The sewage quality varied according to, e.g. moments of rainfall and snowmelt, and its temperature was related to the time of the year. The average quality of sewage to the plant after primary settling was as follows $(\overline{\mathbf{x}} \pm s)$ :

$$
\begin{aligned}
& \mathrm{SS}=196 \pm 61 \mathrm{mg} \mathrm{l}^{-1} \\
& \mathrm{BOD}_{7}=110 \pm 39 \mathrm{mg} \mathrm{l}^{-1} \\
& \mathrm{COD}=169 \pm 6 \mathrm{mg} \mathrm{l}^{-1} \\
& \mathrm{P}_{\text {tot }}=6.0 \pm 2.2 \mathrm{mg} \mathrm{l}^{-1} \\
& \mathrm{COD}_{\mathrm{aq}}=90 \pm 25 \mathrm{mg} \mathrm{l}^{-1} \\
& \mathrm{P}_{\mathrm{aq}}=3.5 \pm 1.7 \mathrm{mg} \mathrm{l}^{-1}
\end{aligned}
$$

The primary settling tank of the test plant was a Dortmund well-type vertical clarifier with a diameter of $2.8 \mathrm{~m}$ and a volume of $14 \mathrm{~m}^{3}$. The aeration basin had a volume of $44 \mathrm{~m}^{3}$ and the aeration air was fed at its bottom.

Like the primary settling tank, the final settling tank was a round Dortmund well-type vertical clarifier with a diameter of $3.5 \mathrm{~m}$, depth of $3.6 \mathrm{~m}$ and volume of $16.8 \mathrm{~m}^{3}$. The final clarifier was dimensioned for a surface load of $1.2 \mathrm{~m}^{2} \mathrm{~h}^{-1}$. The inflow was fed at the center of the tank and the effluent withdrawn from the periphery. Sludge was accumulated due to gravity, and the sludge recycle pumping took place at the conical bottom of the tank (Fig. 7).

The conditions at the test plant were kept as constant as possible during the experiments: Dissolved oxygen level in the aeration basin was maintained in excess of $1.5 \mathrm{mg} \mathrm{l}^{-1}$. Chemicals dosing was held at a constant level of $120 \mathrm{~g} \mathrm{~m}^{-3}$ ferrous sulfate $\left(\mathrm{FeSO}_{4} \cdot 7 \mathrm{H}_{2} \mathrm{O}\right)$, which was fed into the channel connecting the primary settling tank to the aeration basin. Sludge recycling flow was generally $50 \%$ of the influent to the plant, however, at least at $7.5 \mathrm{~m}^{3} \mathrm{~h}^{-1}$, which is the minimum capacity of return pumps. Sludge recycling was increased during those tests of increased loading which were performed in order to investigate the effect of recycling on the operation of the clarifier.

The test runs were designed to simulate flow variations due to rainfall and snowmelt waters at wastewater treatment plants. The test plant, with its design flow of $10 \mathrm{~m}^{3} \mathrm{~h}^{-1}$ was loaded by pumping over a short time period (approx. 5..6 hours) a peak load simulating flow with $\mathrm{Q}_{\max }$ of about $20,25,30$, or $35 \mathrm{~m}^{3} \mathrm{~h}^{-1}$. The test plant was loaded at the aforementioned levels once or twice daily. Loading was increased in steps to a level of
$0.5 Q_{\max }$ at 9:00 and to a level of $Q_{\max }$ at 11:00, from which it was respectively reduced, first from a level of $0.5 \mathrm{Q}_{\max }$ at 13:00 and to the initial value at about $14: 00$ or $15: 00$.

In initial states preceding the flow peaks, the effluent water quality from the final clarifier varied (SS, $\bar{x} \pm s=17 \pm 13 \mathrm{mg} \mathrm{l}^{-1}, \mathrm{n}=25$ ) although the loading (at a constant level) was maximally at the design flow level. (E.g. on Sept. 15, 1982 at 9:00, the solids concentration of effluent was $10 \mathrm{mg} \mathrm{l}^{-1}$, while correspondingly on April 8,1983 at 9:00 also in the beginning of the test, the concentration was $39 \mathrm{mg} \mathrm{l}^{-1}$.)

The effluent water quality from the clarifier was sampled at $30 \mathrm{~min}$ intervals while the flow was increased in steps. The effect of each load increase to the effluent water quality was computed by comparing the measured value (SS, COD and $\mathrm{P}_{\text {tot }} \mathrm{mg} \mathrm{1}^{-1}$ ) to the corresponding value of the initial state preceding the load test $\left(\mathrm{SS}_{\mathrm{a}}, \mathrm{COD}_{\mathrm{a}}\right.$,

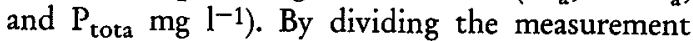
value of the sample from increased loading state by the value of the initial state (e.g. SS/SS ${ }_{2}$ ), relative change factors are obtained, from which the arithmetic means were computed (Fig. 17, p. 21).

Regarding the load parameters, which were the hydraulic surface load $\left(\mathrm{L}_{\mathrm{Q} / \mathrm{A}}\right)$ and the sludge volume load $\left(\mathrm{L}_{\mathrm{SV} / \mathrm{A}}=\mathrm{L}_{\mathrm{Q} / \mathrm{A}} \times\right.$ MLSS $\left.\times \mathrm{SVI}\right)$, the corresponding averages were calculated. Only those test results were accepted, during which the sludge blanket surface was clearly $(\geq 50 \mathrm{~cm})$ below the clarifier liquid surface and no solids loss occurred from the sludge blanket.

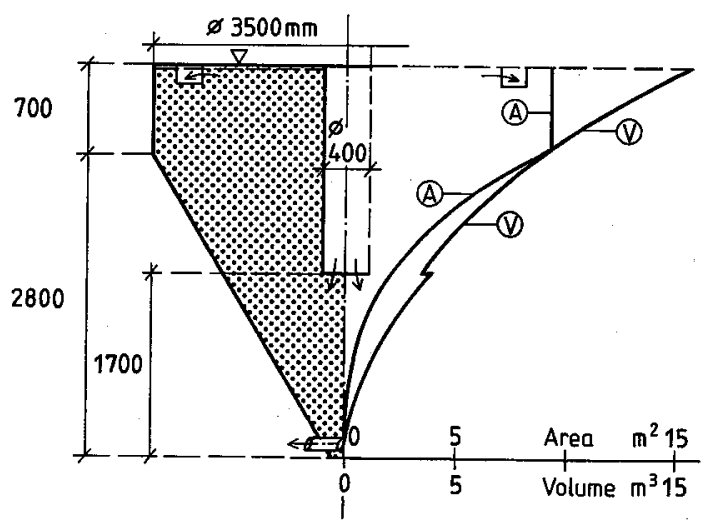

Fig. 7. Vertical clarifier: area (A), and volume (V) at different levels. 


\subsection{Determination of sludge settling velocity}

The simulation model developed and presented in this study for investigation of the solids concentration and height variations of a sludge blanket in a clarifier presupposes the availability of sludge settling velocities. The settling velocities to be later used in running the model were first determined as zone settling velocities, i.e., the settling velocities of the sludge blanket surface from calibration cylinder tests. The effect of depth on the settling velocity was taken into account in the model calibration by increasing the settling velocity with the increased depth of the sludge blanket.

Since the model verification proved unsatisfactory when the zone settling velocities were used, the settling velocities were re-evaluated from concentration measurement results taken directly from the sludge blanket. The measurement was taken before the load increase (from 8:00 to 9:00) when the settling and thickening process in the clarifier was in an equilibrium or steady state.

\subsubsection{Determination of zone settling velocity by cylinder tests}

The zone settling velocity was determined by using a transparent test cylinder graduated with a fixed scale. The cylinder diameter was $12.7 \mathrm{~cm}$ and height $95.7 \mathrm{~cm}$. In order to eliminate the wall effect, cylinders of different size were tested in the determination measurements. The settling velocities at different solids concentrations were obtained by measuring the velocities from return sludge diluted with treated effluent, from the activated sludge of the aeration basin, and from sludge taken from the upper part of the clarifier.

The test plant was generally operated using a short sludge age during the flow change tests. Hence, the zone settling velocity was primarily determined at a short sludge age (about $3 \mathrm{~d}$ ). In addition, the test plant was run at a longer sludge age (about $14 \mathrm{~d}$ ) in order to discover the significance of sludge age. The zone settling tests were also performed at different temperatures by cooling and diluting the return sludge taken from the treatment plant. The greatest temperature differences during the settling tests were in the order of $10^{\circ} \mathrm{C}$.

In addition to zone settling velocities obtained from the sylinder tests, the settling velocity of the sludge blanket surface was also measured in the final clarifier after the clarifier inflow and sludge recycling was stopped in the clarifier. The test intended to determine the correspondence between the cylinder tests and the settling velocity of the clarifier sludge blanket.

\subsubsection{Effect of depth on sludge settling velocity}

Sludge settling velocities are generally assumed to increase with the sludge blanket depth because the size of sludge particles grows in this direction. In the study, changes in sludge blanket density were measured at different depths as a function of time in order to determine the effect of blanket depth. The measurements are originally performed in two series, and later in one vertical series with the measurement points spaced at about $0.5 \mathrm{~m}$ distances, and included two or several measurements at each depth. The duration of measurement series procedures and sludge settling and thickening was about $0.5 \ldots 1.0 \mathrm{~h}$.

The solids concentrations were measured using a photometer with its detector immersed in the sludge in the clarifier. Measurement results from the photometer were directly readable after calibration. Meter readings taken in the immediate vicinity of the feed pipe orifice (depth $1.5 \mathrm{~m}$ and $2.0 \mathrm{~m}$ ) showed a slight variation. Consequently, the values of sludge concentration were selected to correspond to the average reading of the photometer. The measurements were performed at one hour intervals between 8:30 and 13:30, during which time the clarifier was loaded by increasing the flow in steps.

In order to determine sludge settling velocity at different depths in the sludge blanket, the clarifier was horizontally divided into six layers (Fig. 8). The inflow and outflow solids quantity of each layer in a time interval (between the measurements) was computed from the concentration changes measured. Computation was started from the bottom layer into which the solids received from above layers was accumulated but was not removed because sludge return from the clarifier was stopped during measurements. The change in solids quantity $\left(\triangle \mathrm{M}_{\mathrm{i}}\right)$ in a certain layer in the time interval between the measurements was calculated as the product of average settling velocity (v) sludge average concentration $(\bar{C})$ of the corresponding area (A) and the time interval $(\Delta t)$ of measurements reduced correspondingly from the layer by the solids quantity ( $\bar{G}=$ solids flux).

$$
\begin{aligned}
& \Delta \mathrm{M}_{\mathrm{i}}=\overline{\mathrm{v}}_{\mathrm{i}} \overline{\mathrm{C}}_{\mathrm{i}} \mathrm{A}_{\mathrm{i}} \Delta \mathrm{t}-\overline{\mathrm{G}}_{\mathrm{i}-1} \mathrm{~A}_{\mathrm{i}-1} \Delta \mathrm{t} \\
& \bar{v}_{\mathrm{i}}=\frac{\Delta \mathrm{M}_{\mathrm{i}}+\overline{\mathrm{G}}_{\mathrm{i}-1} \mathrm{~A}_{\mathrm{i}-1} \Delta \mathrm{t}}{\overline{\mathrm{C}}_{\mathrm{i}} \mathrm{A}_{\mathrm{i}} \Delta \mathrm{t}}
\end{aligned}
$$




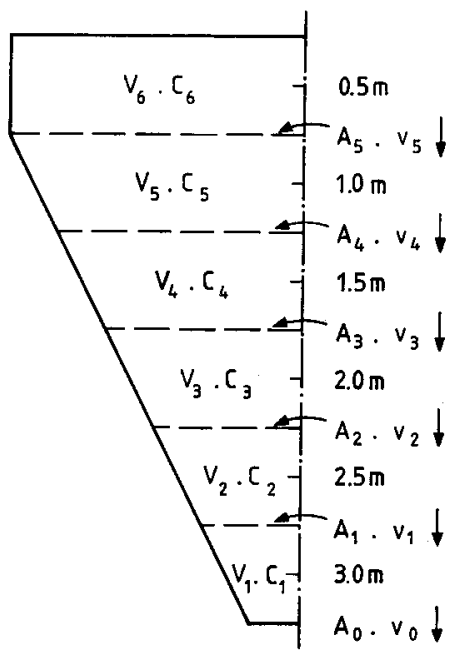

$A=$ incerface area $\left(\mathrm{m}^{2}\right)$

$\mathrm{C}=$ solids concentration $\left(\mathrm{g}^{-1}\right)$

$\mathrm{V}=$ layer volume $\left(\mathrm{m}^{3}\right)$

$\mathrm{v}=$ settling velocity $\left(\mathrm{m} \mathrm{h}^{-1}\right)$

Fig. 8. Division of clarifier colume into layers $1 \ldots 6$ for determining sludge settling velocity from solids concentration measurements of sludge blanket at different depths.

In the lowest layer, $\overline{\mathrm{G}}_{0}=0$

$\bar{v}_{1}=\frac{\Delta M_{1}}{\bar{C}_{1} A_{1} \Delta t}$

\subsubsection{Determination of settling velocity from sludge blanket steady state}

Solids concentrations of the sludge blanket measured before load increase (between 8:00 and 9:00) were used as initial values in the determination of settling velocity. These results were measured when the process was operating in a steady state so that the influent and effluent solids flux, as well as the sludge blanket height and concentrations at different depths, were kept constant in excess of one hour.

When the process is in steady state, we can write Equation (1) as follows:

$\mathrm{V}_{\mathrm{i}} \frac{\partial \mathrm{C}_{\mathrm{i}}}{\partial \mathrm{t}}=0$

which indicates that the solids quantity in any layer (i) of the clarifier sludge blanket is constant. Then, the equation can be solved for the sludge settling velocity:

$\mathrm{v}_{\mathrm{i}}=\mathrm{f}\left(\mathrm{C}_{\mathrm{i}}\right)=\mathrm{k}_{1} \mathrm{C}_{\mathrm{i}}^{-\mathrm{k}_{2}}$
The settling velocity (graph $v=f(C)$ ) can be determined by estimating the value of coefficients $\mathrm{k}_{1}$ and $\mathrm{k}_{2}$ in equation (17) so that the limiting concentration $\left(\mathrm{C}_{\mathrm{L}}\right)$ obtained from equation $(10)$ is to within a sufficient accuracy equal to the measured value $\left(\mathrm{C}_{\mathrm{L}}\right)$ in equation (17). The obtained velocities are then verified by simulating the steady-state process conditions in model runs (for times between 8:00 and 9:00).

If the concentration measurement results contain a deviation so that graph $v=f(C)$ has been forced to be fitted or, in lack of measurement values, extrapolated, the settling velocity $\left(v_{L}\right)$ corresponding to the limiting solids flux at the feed pipe orifice level can be solved from the equation by utilizing the measured limiting solids concentration $\left(C_{L}\right)$. Next, coefficients $k_{1}$ and $k_{2}$ of the aforementioned equation are iterated with the help of equations (17) and (10).

The effect of sludge blanket height on sludge settling velocity was determined according to the method described in the foregoing, and the intermediate values of velocity were interpolated linearly. If the result obtained was satisfactory in the steady state, the dynamic simulation performed using the same settling velocities was also successful (for times between 9:00 and 14:00).

\section{RESULTS OF TEST RUNS}

\subsection{Sludge blanket behaviour during load variations}

When the loading is increased in steps, the solids profile of the clarifier is retained closely unchanged so that the sludge blanket concentration in each loading phase above the feed pipe orifice (depth 1.8 $\mathrm{m}$ ) is approximately constant in the vertical direction. Below the feed point, sludge is thickened and concentration increases in relation to depth (Fig. 9a).

During an increased flow (between $8: 30$ and 11:30) (Fig. 9a) the graph depicting solids concentration at different depths is shifted to the left, indicating a decreased concentration from top to bottom. However, the sludge blanket surface simultaneously raises, which indicates solids buildup in the upper part of the clarifier. Due to the decreased flow, (from 11:30 to 13:30), the solids profile is correspondingly shifted to the right, indicating sludge thickening in the clarifier also causing the sludge blanket top level to sink. In the 

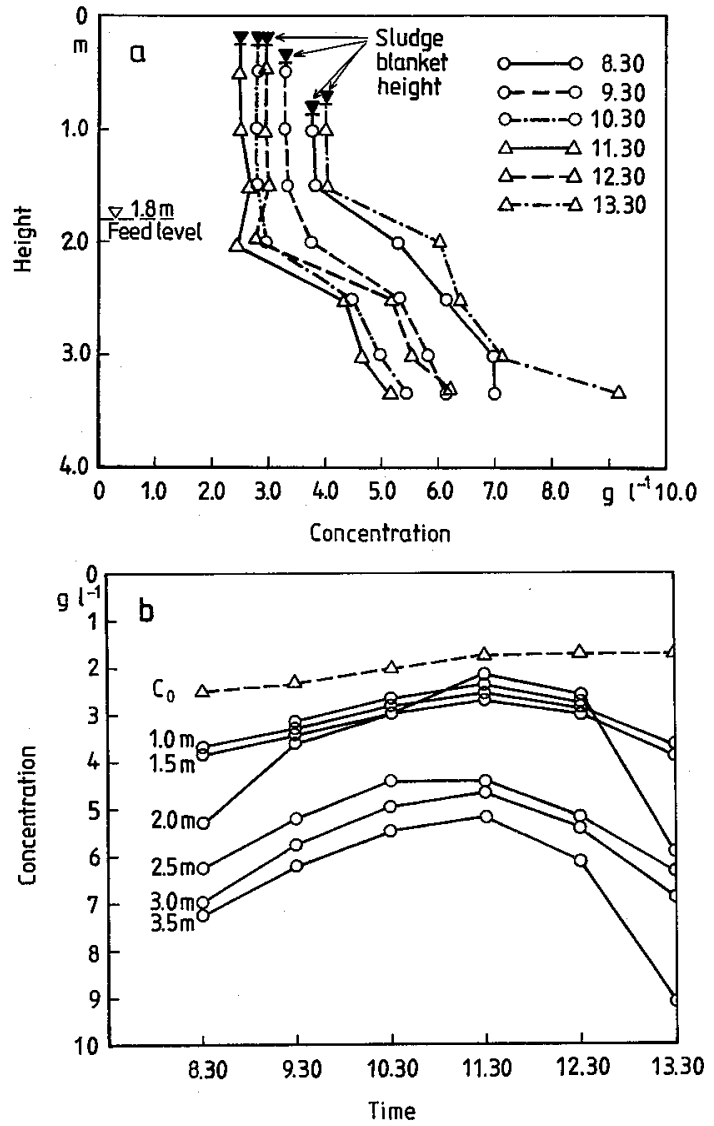

Fig. 9. a) Changes in clarifier sludge blanket top level and solids concentration due to changes in loading (test performed on May 24, 1984). b) Equal changes of concentration at different depths.
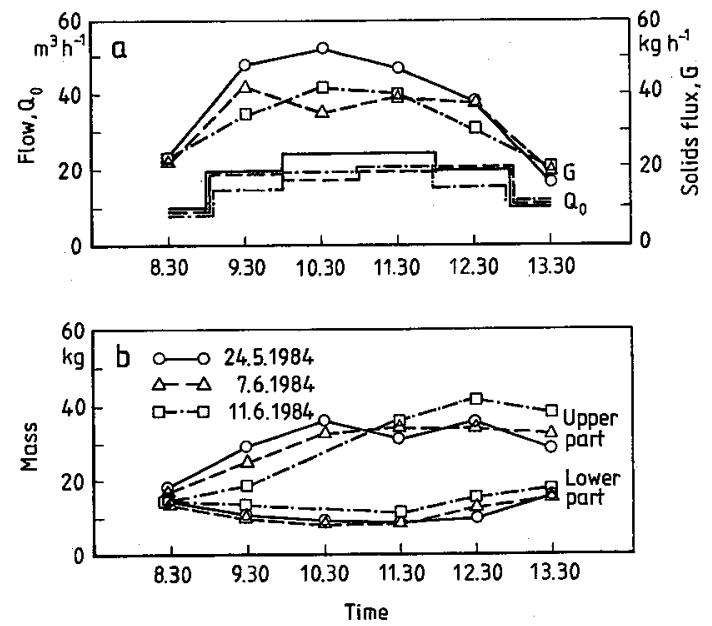

Fig. 10. a) Variations in flow $\left(Q_{0}\right)$ and solids flux $(G=$ $\mathrm{Q}_{0} \mathrm{C}_{0}$ ) during a test. b) Variations in solids mass during the test in upper and lower parts of clarifier. test, sludge return flow was $50 \%$ of influent flow to the treatment plant.

When the recycle flow was increased (e.g. up to $100 \%$ ), the concentration in the lower part of the sludge blanket was decreased to the concentration level of the upper part, which is shown as an approximately vertical graph (in Fig. 9a) indicating a constant concentration throughout the entire blanket. Consequently, the sludge did not have sufficient time to settle and thicken at the rate required by recovery of the clarifier. By contrast, the sludge blanket height changed as described above.

The concentration level changes were most acute below the feed pipe orifice, or at the measurement level of $2.0 \mathrm{~m}$, to which level solids from the feed pipe (depth $1.8 \mathrm{~m}$ ) was "raining". It was also observed that the influent solids concentration $\left(C_{0}\right)$ was not found anywhere in the clarifier but the activated sludge entering the clarifier was thickened immediately. Thickening was most effective during the reduced flow (from 11:30 to 13:30). During increasing flow (8:30 to $11: 30)$, the solids concentration decreased (Fig. 9b). Due to increased loading (Fig. 10a), the accumulation of solids in the clarifier increased by about $30 .$. . $100 \%$ (from 8:30 to 13:30) in accordance with Fig. 10b. Build-up was primarily concentrated above the initial sludge blanket top level, which was mostly also the storage volume available above the feed pipe orifice. Build-up in the lower part of the clarifier was observed only during a decreased solids flow.

\subsection{Sludge settling velocity}

The sludge settling velocity required for the simulation model was first determined by the conventional cylinder test as the zone settling velocity, from which the velocities applies to the deeper depths of the sludge blanket were determined in conjunction with the model calibration. Since the model operated unsatisfactorily at the aforementioned calculated velocities, a new method was developed for direct computation of velocities from measurement results of concentration from the clarifier with the process operating in steady state. Although the zone settling velocities do not with sufficient accuracy determine the sludge settling velocity within the sludge blanket, these velocities can, however, be used for estimating the factors of sludge settling velocity in simulation models. 


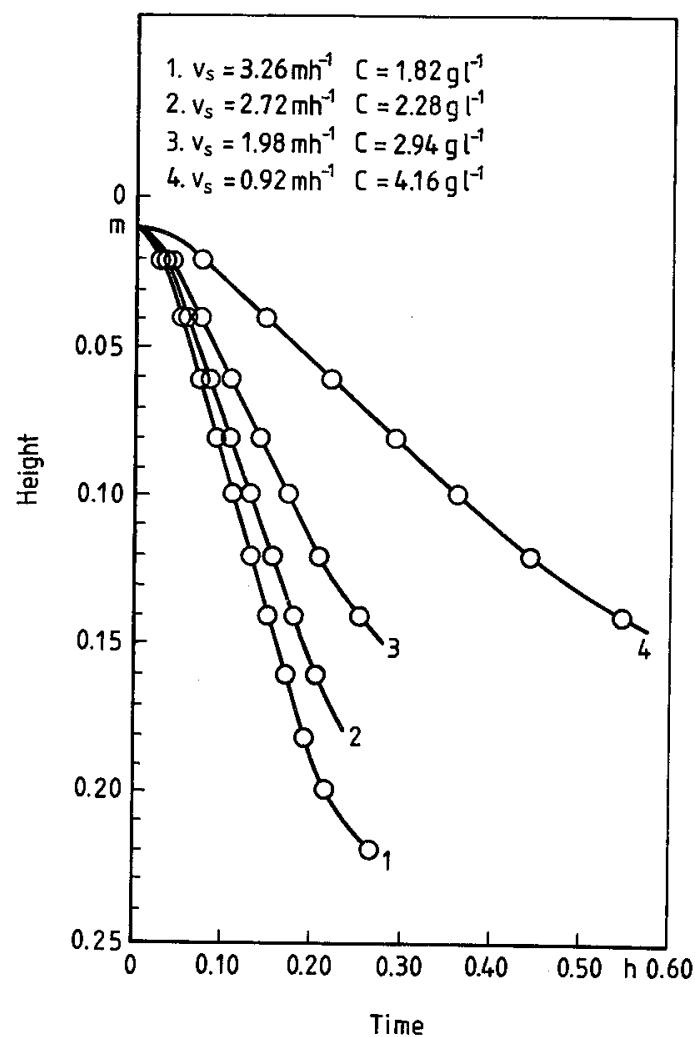

Fig. 11. Sinking of sludge blanket top level (zone settling) in a calibration cylinder as a function of time. The slope of graphs is equal to the zone settling velocity $\left(v_{s}\right)$ for different solids concentrations $(C)$.

\subsubsection{Zone settling velocities}

The settling velocity measurement of sludge blanket top level for a certain solids concentration assumes performing a calibration cylinder test. Each graph in Fig. 11 represents one test and its straight part corresponds to the unhindered settling velocity of the sludge blanket top level for the corresponding solids concentration. In other words, this velocity can be interpreted as the settling velocity before sludge thickening in the lower layers of the cylinder begin to hinder the sinking of sludge blanket top level. The zone settling velocity $\left(v_{s}\right)$ is equal to the slope of the graph in Fig. 11.

Zone settling velocities were measured (Table 2) for sludges of different ages (about $3 \mathrm{~d}$ and about $14 \mathrm{~d}$, Fig. 12). In the measurements, temperature

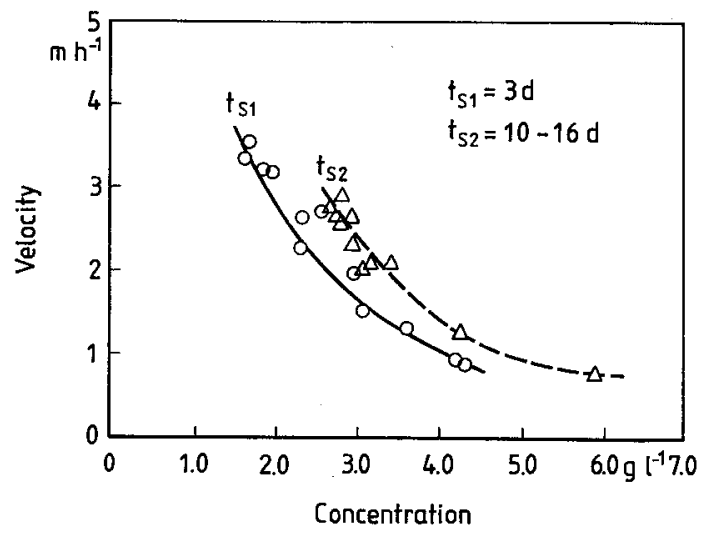

Fig. 12. Dependence of zone settling velocity on solids concentration in calibration cylinder tests for two sludge types of different ages $\left(t_{s}=3 \mathrm{~d}\right.$ and $\left.t_{s}=10 \ldots 16 \mathrm{~d}\right)$. Temperature $\mathrm{T}=11.6 \ldots 13.6{ }^{\circ} \mathrm{C}($ Table 2$)$.

Table 2. Zone settling velocity $\left(\mathrm{v}_{\mathrm{s}}\right)$ of calibration cylinder tests for different solids concentrations $(\mathrm{C})$ and different sludge age groups $\left(\mathrm{t}_{\mathrm{s}}\right)$ (Fig. 12).

\begin{tabular}{|c|c|c|c|c|}
\hline Date & $\begin{array}{c}\mathrm{v}_{\mathrm{s}} \\
\mathrm{m} \mathrm{h}^{-1} \\
\end{array}$ & $\begin{array}{c}\mathrm{C} \\
\mathrm{g} \mathrm{l}^{-1}\end{array}$ & $t_{s}$ & $\begin{array}{l}\mathrm{T} \\
{ }^{\circ} \mathrm{C} \\
\end{array}$ \\
\hline 26.11.-84 & 1.30 & 3.57 & 3.1 & 1.3 \\
\hline $26.11 .-84$ & 2.34 & 2.31 & 3.1 & 1.3 \\
\hline $26.11 .-84$ & 3.41 & 1.63 & 3.1 & 1.3 \\
\hline $26.11 .-84$ & & & & \\
\hline $21.11 .-84$ & 0.91 & 4.25 & 2.9 & 13.6 \\
\hline 21.11. -84 & 1.55 & 3.06 & 2.9 & 13.6 \\
\hline 21.11.-84 & 3.21 & 1.91 & 2.9 & 13.6 \\
\hline 21.11.-84 & 3.60 & 1.59 & 2.9 & 13.6 \\
\hline $21.11 .-84$ & 2.73 & 2.56 & 2.9 & 13.6 \\
\hline 16.11.-84 & 0.92 & 4.16 & 3.1 & 13.6 \\
\hline & 1.98 & 2.94 & 3.1 & 13.6 \\
\hline $16.11 .-84$ & 2.72 & 2.28 & 3.1 & 13.6 \\
\hline $16.11 .-84$ & 3.26 & 1.82 & 3.1 & 13.6 \\
\hline
\end{tabular}

\begin{tabular}{lcccc}
\hline Date & $\begin{array}{c}\mathrm{v}_{\mathrm{s}} \\
\mathrm{m} \mathrm{h}^{-1}\end{array}$ & $\begin{array}{c}\mathrm{C} \\
\mathrm{g} \mathrm{l}^{-1}\end{array}$ & $\begin{array}{c}\mathrm{t}_{\mathrm{s}} \\
\mathrm{d}\end{array}$ & $\begin{array}{c}\mathrm{T} \\
{ }^{\circ} \mathrm{C}\end{array}$ \\
\hline $17.12 .-84$ & 1.74 & 3.89 & 14.5 & 11.8 \\
17.12 .84 & 0.75 & 5.90 & 14.5 & 11.8 \\
$17.12 .-84$ & 2.92 & 2.80 & 14.5 & 11.8 \\
$17.12 .-84$ & 2.67 & 2.76 & 14.5 & 11.8 \\
& & & & \\
$13.12 .-84$ & 2.81 & 2.60 & 10.2 & 11.6 \\
$13.12 .-84$ & 2.67 & 2.92 & 10.2 & 11.6 \\
$13.12 .-84$ & & & 10.2 & 11.6 \\
$13.12 .-84$ & 2.60 & 2.78 & 10.2 & 11.6 \\
$13.12 .-84$ & 2.28 & 2.94 & 10.2 & 11.6 \\
& & & & \\
$12.12 .-84$ & 2.10 & 3.41 & 15.9 & 11.6 \\
$12.12 .-84$ & 1.26 & 4.25 & 15.9 & 11.6 \\
$12.12 .-84$ & 1.97 & 3.03 & 15.9 & 11.6 \\
$12.12 .-84$ & 2.08 & 3.15 & 15.9 & 11.6 \\
\hline
\end{tabular}


varied within the range of $11.6 \ldots 13.6^{\circ} \mathrm{C}$. Zone settling velocities obtained for sludges of a greater age (about $14 \mathrm{~d}$ ) were distinctly higher (about $1.0 .0 .4 \mathrm{~m} \mathrm{~h}^{-1}$ within concentration range of $2.5 \ldots 4.25 \mathrm{~g} \mathrm{l}^{-1}$ ) as compared to results obtained from sludges of a less age $(F=7.09$ at $1 \%$ risk level from variance analysis performed on the regression line). With increasing sludge concentration (above $5 \mathrm{~g} \mathrm{l}^{-1}$ ), the difference, according to the results, is reduced to an insignificant level in practical terms.

Furthermore, the zone settling velocities were measured for sludges of different temperatures (Fig. 13 and Table 3). Temperature difference in the test conditions was about $10 \ldots 12^{\circ} \mathrm{C}$, and was obtained by cooling a portion of the sludge outdoors during the cold season and by storing the other portion inside at the test station. The initial temperature of wastewater was about $10^{\circ} \mathrm{C}$ and the sludge age about $13 \mathrm{~d}$. Solids concentration of sludge was altered by diluting the sludge with

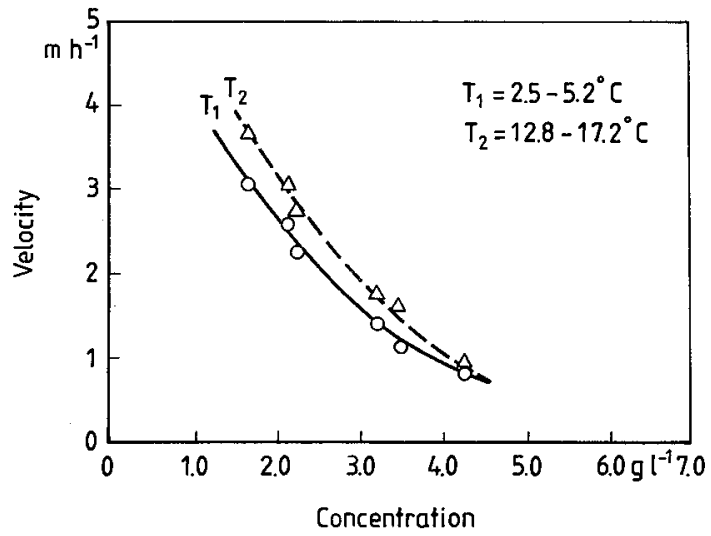

Fig. 13. Dependence of sludge zone settling velocity on solids concentrations within two different temperature ranges $\left(\mathrm{T}_{1}=12.8 \ldots 17.2^{\circ} \mathrm{C}\right.$ and $\left.\mathrm{T}_{2}=2.5 \ldots 5.2^{\circ} \mathrm{C}\right)$. Sludge age $t_{s}=3 \mathrm{~d}$ (Table 3 ).

Table 3. Zone settling velocities $\left(v_{s 1}\right.$ and $v_{s 2}$ ) of calibration cylinder tests for different solids concentrations (C) and temperature groups $\left(\mathrm{T}_{1}\right.$ and $\left.\mathrm{T}_{2}\right)$ (Fig. 13).

\begin{tabular}{lcccccc}
\hline Date & $\begin{array}{c}\mathrm{C} \\
\mathrm{g} \mathrm{l}^{-1}\end{array}$ & $\begin{array}{c}\mathrm{t}_{\mathrm{s}} \\
\mathrm{d}\end{array}$ & $\begin{array}{c}\mathrm{T}_{1} \\
{ }^{\circ} \mathrm{C}\end{array}$ & $\begin{array}{c}\mathrm{v}_{\mathrm{s} 1} \\
\mathrm{~m} \mathrm{~h}^{-1}\end{array}$ & $\begin{array}{c}\mathrm{T}_{2} \\
{ }^{\circ} \mathrm{C}\end{array}$ & $\begin{array}{c}\mathrm{v}_{\mathrm{s} 2} \\
\mathrm{~m} \mathrm{~h}^{-1}\end{array}$ \\
\hline $30.1 .-85$ & 4.24 & 13 & 14.0 & 0.92 & 5.2 & 0.77 \\
$31.1 .-85$ & 2.21 & 13 & 16.2 & 2.73 & 2.5 & 2.31 \\
$4.2 .-85$ & 1.61 & 13 & 17.2 & 3.09 & 3.7 & 3.12 \\
$20.2 .-85$ & 2.10 & 13 & 12.8 & 3.07 & 4.2 & 2.60 \\
$26.2 .-85$ & 3.47 & 13 & 17.9 & 1.64 & 4.1 & 1.11 \\
$27.2 .-85$ & 3.20 & 13 & 16.4 & 1.78 & 4.1 & 1.42 \\
$21.1 .-85$ & 4.23 & 13 & & & 5.0 & 0.86 \\
\hline
\end{tabular}

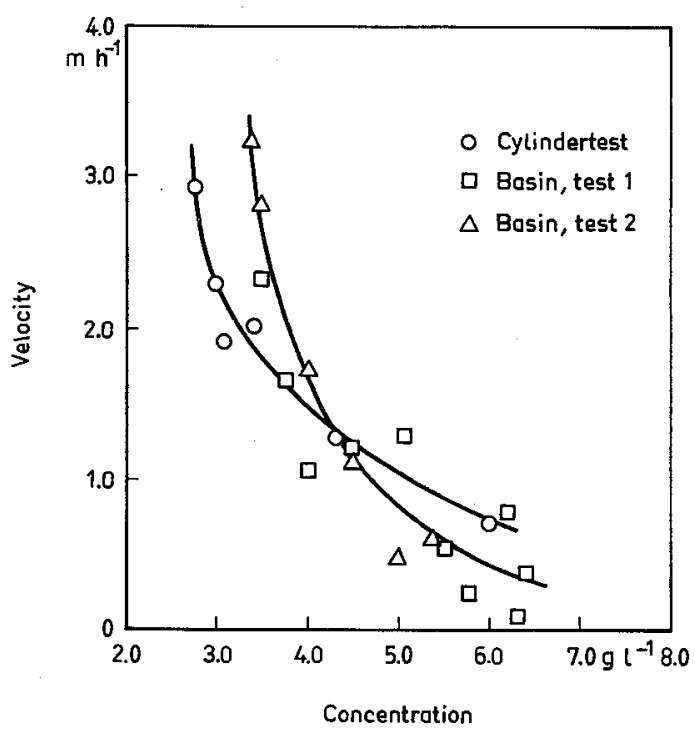

Fig. 14. Sludge settling velocities in clarifier and calibration cylinder tests for different solids concentration (Table 4).

Table 4. Zone sertling velocities $\left(v_{s 1}, v_{s 2}\right.$ and $\left.v_{v 3}\right)$ of calibration cylinder and clarifier tests for different solids concentrations (C) (Fig. 14).

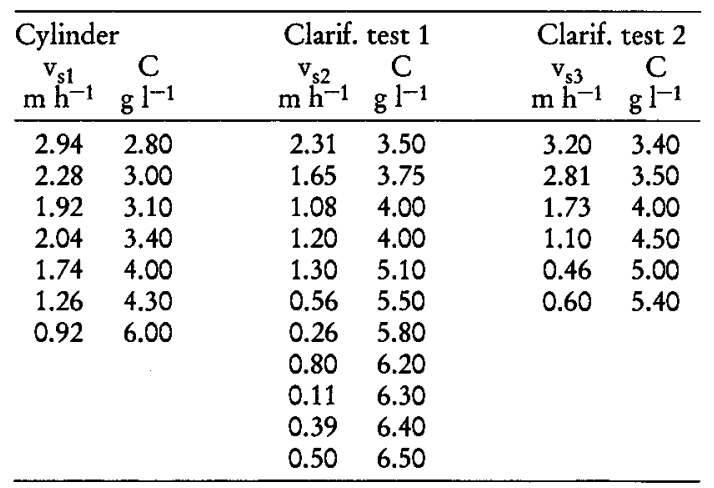

treated wastewater. Settling velocities obtained for higher temperatures (about $13 \ldots 17^{\circ} \mathrm{C}$ ) were higher (approx. 0.4 .0.2 $\mathrm{m} \mathrm{h}^{-1}$ ) within the aforementioned concentration range of $\mathrm{C}=2.5 \ldots$ $4.25 \mathrm{~g} \mathrm{l}^{-1}$, as compared to results obtained at lower temperatures $\left(2.5 \ldots 5.2^{\circ} \mathrm{C}\right)$. In practice, temperature differences at sludge concentrations in excess of $4 \mathrm{~g} \mathrm{I}^{-1}$ are insignificant. A statistically significant difference was neither found in settling speeds in sample groups of different temperatures.

Settling velocities of a sludge blanket top level in a clarifier which is shut off (Fig. 14 and Table 4), 
were, on the average, higher than settling velocities measured in the calibration cylinder when sludge concentration was below $4.3 \mathrm{~g} \mathrm{l}^{-1}$ and lower when concentration was above $4.3 \mathrm{~g} \mathrm{l}^{-1}$. The concentration in the clarifier was measured at the upper part of the sludge blanket during its thickening, which is not fully compliant with the procedure in calibration cylinder tests where concentration in the beginning of the test is homogeneous throughout the cylinder.
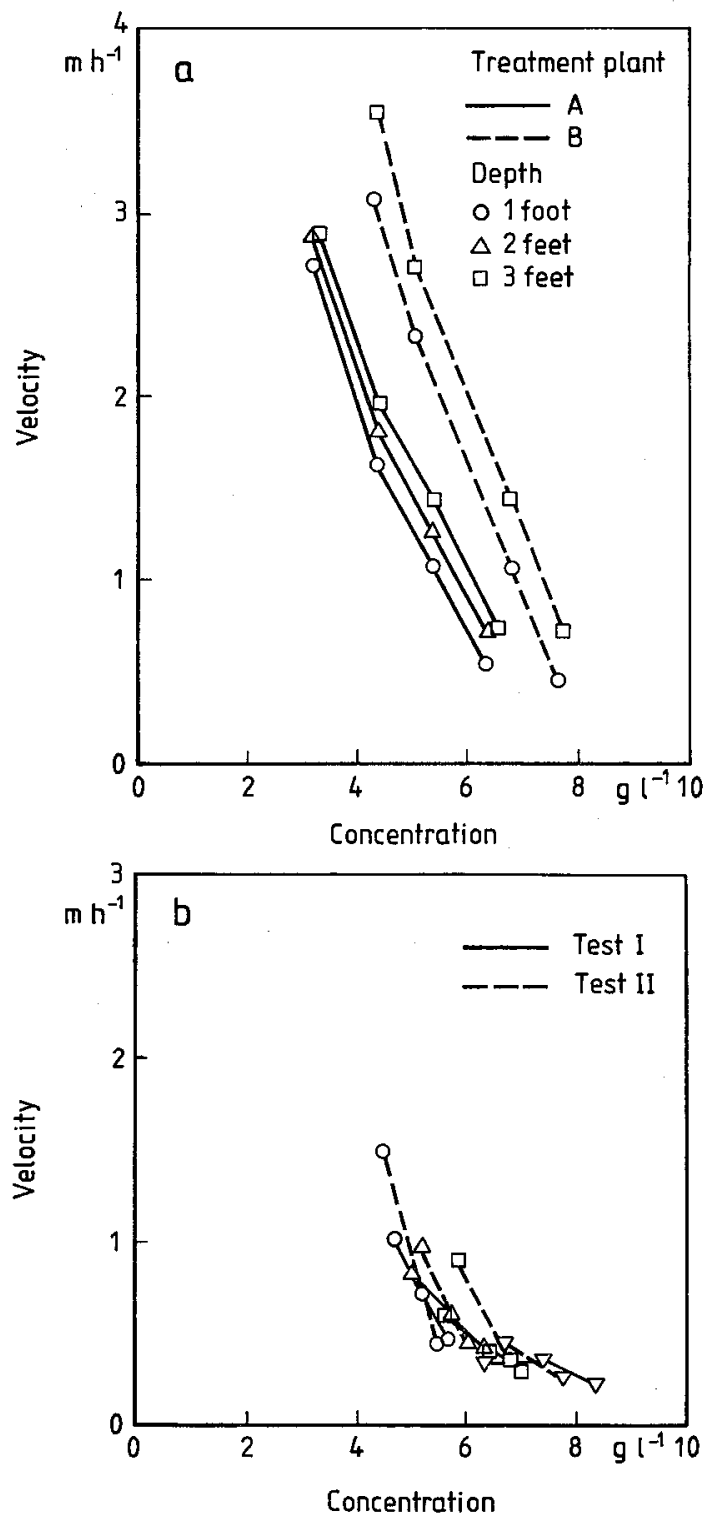

Fig. 15. Sludge settling velocity as a function of sludge concentration at different depths. a) According to Dick and Eving (1967). b) Measured from solids concentration in clarifier (Dec. 13, 1984).

\subsubsection{Depth effect on sludge settling velocity}

Sludge settling velocities computed from the results of Dick and Eving (1967) are shown in Fig. 15a. According to these, an increase of depth by $0.6 \mathrm{~m}(2 \mathrm{ft})$ increased sludge settling velocity by $0.3 \ldots 0.4 \mathrm{~m} \mathrm{~h}^{-1}$. Settling velocity results obtained from different plants $A$ and $B$ differ from each other but the depth effect on sludge settling velocity is approximately equal in both plants.

Sludge settling velocities within the sludge blanket were calculated from the concentration measurement results of the sludge blanket. The obtained results (Fig. 15b, Test II) were in the same order of magnitude as indicated above.A depth increase of $0.5 \mathrm{~m}$ increased settling velocity by $0.3 \ldots 0.4 \mathrm{~m} \mathrm{~h}^{-1}$. Depth dependent differences in Test I were not as distinctive. By contrast, other tests performed supported test results from Test II.

\subsubsection{Settling velocities in steady state of clarifier}

Settling velocities computed from concentration results of the clarifier sludge blanket operating in a steady state (for instance, in tests on Nov. $16 . .26,1984)$ were, on the average, higher than corresponding velocities obtained from calibration cylinder tests. The sludge concentration was then about $2 \ldots 4 \mathrm{~g} \mathrm{I}^{-1}$ corresponding to sludge velocities found in the upper part of the clarifier. The velocity difference increased rapidly as concentration decreased (Fig. 16 and Table 5). The calculated velocities were based on measurements performed at depths of $0.9 \ldots 1.8 \mathrm{~m}$.

A distinct increase with depth is observed in the velocities. Velocities obtained from conventional cylinder tests are generally too low compared to the results from the clarifier measurements (at concentrations $<4 \mathrm{~g}^{-1}$ ).

\subsection{Effect of load variation on effluent quality from clarifier}

Doubling the hydraulic surface load $\left(\mathrm{L}_{\mathrm{Q} / \mathrm{A}}\right)$ to a level of $\mathrm{L}_{\mathrm{Q} / \mathrm{A}}=2.4 \mathrm{~m} \mathrm{~h}^{-1}$ compared to the design flow $\left(1.2 \mathrm{~m} \mathrm{~h}^{-1}\right)$ increased the effluent water solids mass (SS) by about $75 \%$, and a 2.5 -fold load level $\left(3.0 \mathrm{~m} \mathrm{~h}^{-1}\right.$ ) by about $150 \%$ compared to the design operating conditions (Fig. 17a and Table 6). 


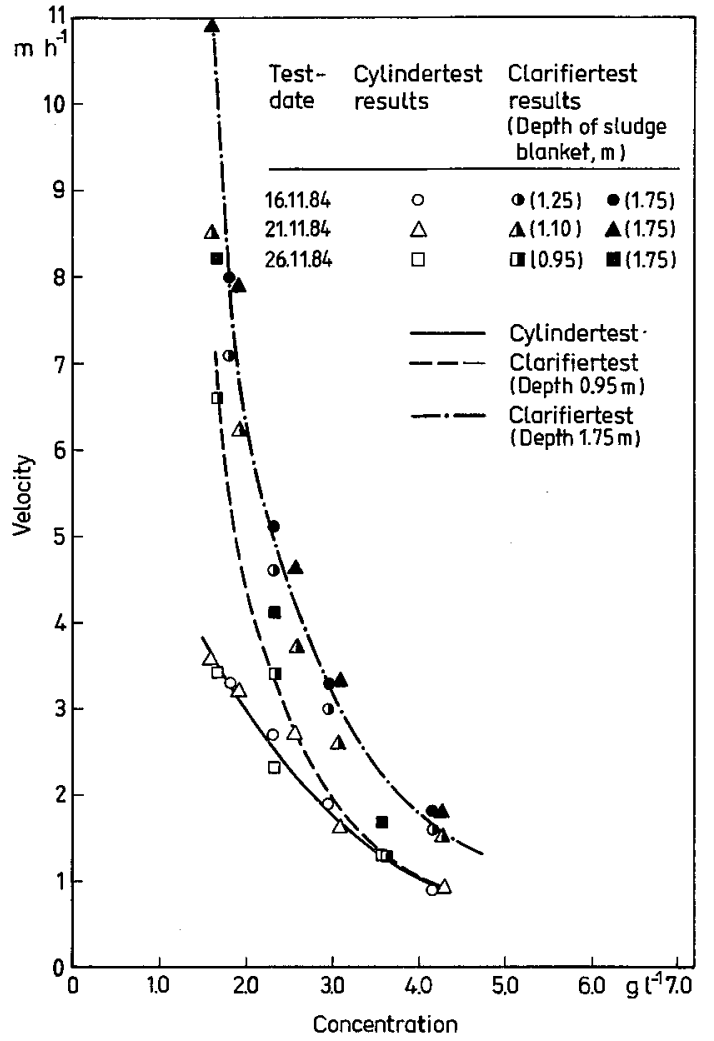

Fig. 16. Zone settling velocities measured in cylinder tests and sludge settling velocities calculated from concentration measurements of the clarifier in a steady state during tests performed on Nov. 16...26, 1984 (Table 5).

Table 5. Sludge settling velocities measured in cylinder tests $\left(\mathrm{v}_{\mathrm{s}}\right)$ and computed from sludge blanket steady state (v) in tests performed on Nov. 16...26, 1984 (Fig. 16).

\begin{tabular}{lcccccc}
\hline Date & $\begin{array}{c}\mathrm{C} \\
\mathrm{g} \mathrm{I}^{-1}\end{array}$ & $\begin{array}{c}\mathrm{v}_{\mathrm{s}} \\
\mathrm{m} \mathrm{h}^{-1}\end{array}$ & $\begin{array}{c}\mathrm{h} \\
\mathrm{m}\end{array}$ & $\begin{array}{c}\mathrm{v} \\
\mathrm{m} \mathrm{h}^{-1}\end{array}$ & $\begin{array}{c}\mathrm{h} \\
\mathrm{m}\end{array}$ & $\begin{array}{c}\mathrm{v} \\
\mathrm{m} \mathrm{h}^{-1}\end{array}$ \\
\hline 16.11.-84 & 1.80 & 3.3 & 1.25 & 7.1 & 1.75 & 8.0 \\
16.11.-84 & 2.30 & 2.7 & 1.25 & 4.6 & 1.75 & 5.1 \\
$16.11 .-84$ & 2.95 & 1.9 & 1.25 & 3.0 & 1.75 & 3.3 \\
16.11.-84 & 4.15 & 0.9 & 1.25 & 1.6 & 1.75 & 1.8 \\
& & & & & & \\
21.11.-84 & 1.60 & 3.6 & 1.10 & 8.5 & 1.75 & 10.9 \\
$21.11 .-84$ & 1.90 & 3.2 & 1.10 & 6.2 & 1.75 & 7.9 \\
$21.11 .-84$ & 2.55 & 2.7 & 1.10 & 3.7 & 1.75 & 4.6 \\
$21.11 .-84$ & 3.05 & 1.6 & 1.10 & 2.6 & 1.75 & 3.3 \\
$21.11 .-84$ & 4.25 & 0.9 & 1.10 & 1.5 & 1.75 & 1.8 \\
& & & & & & \\
$26.11 .-84$ & 1.65 & 3.4 & 0.95 & 6.6 & 1.75 & 8.2 \\
$26.11 .-84$ & 2.30 & 2.3 & 0.95 & 3.4 & 1.75 & 4.1 \\
$\mathbf{2 6 . 1 1 . - 8 4}$ & 3.55 & 1.3 & 0.95 & 1.4 & 1.75 & 1.7 \\
\hline
\end{tabular}

The increase of total phosphorus $\left(P_{\text {tot }}\right)$ in effluent for the same values of surface load was about $25 \%$ and $50 \%$, which is a third of solids quantity increase.

Changes in chemical oxygen demand (COD) were correspondingly in the order of $5 \%$ and $25 \%$.

The relatively smaller increase in quantities of total phosphorus and chemical oxygen demand compared to the increase in solids quantity in effluent is caused by the fact that a significant portion (a third of total phosphorus) is in soluble form and not bound to the solids.

While the tests were conducted, the solids load at the test plant was approx. $0.3 \mathrm{~kg} \mathrm{~kg}^{-1} \mathrm{~d}^{-1}$ (with a variation range of $\left.0.1 \ldots 0.8 \mathrm{~kg} \mathrm{~kg}^{-1} \mathrm{~d}^{-1}\right)$. The sludge volume load of the clarifier $\left(\mathrm{L}_{\mathrm{SV} / \mathrm{A}}\right)$ was at a low level $\left(0.3 \ldots 0.5 \mathrm{~m} \mathrm{~h}^{-1}\right)$ during load increases as compared to the design loading value $\left(0.6 \mathrm{~m} \mathrm{~h}^{-1}\right)$ (Fig. 17b).

Sludge loss from the clarifier was dependent on the initial top level of the sludge blanket immediately before load increase in addition to the increase of flow. Flow increase to a level of 2 2..2.5-fold at a constant flow concentration required a sludge volume with a height in excess of $1 \mathrm{~m}$ in the clarifier, and a settling volume of about $0.5 \mathrm{~m}$ above it.

\section{MODEL TESTING AND RESULTS}

\subsection{Model calibration and verification}

Sludge settling velocity depends on several factors including, e.g., its quality. A well-settling sludge forms large agglomerations, or flocs, which further grow during the settling of the sludge. Therefore, the settling velocity increases with depth. The model has been calibrated by determining this settling velocity at a certain depth and characterizing it by a function $\mathrm{v}=\mathrm{f}(\mathrm{C})$ (Fig. 18). Different depths are described with different functions by varying coefficient $k_{1}$. Coefficient $k_{2}$ was assumed constant.

Values of coefficient $k_{1}$ at different depths of the sludge blanket are obtained by computation from the results of concentration measurements performed during the steady state of the process. The clarifier was maintained in steady state using at least two different heights of the sludge blanket in order to be able to determine the values of $k_{1}$ 

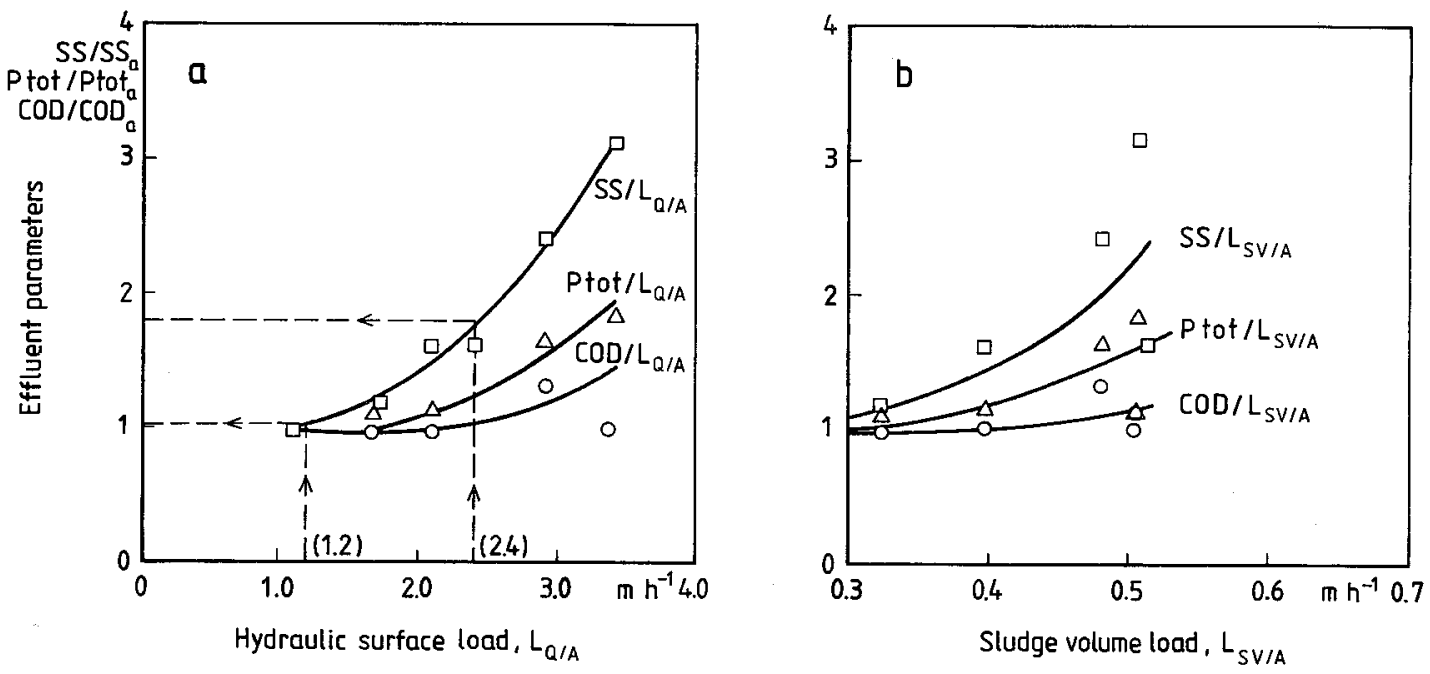

Fig. 17. a) Effect of hydraulic surface load $\left(\mathrm{L}_{\mathrm{Q} / \mathrm{A}}\right)$ increase on effluent water quality. b) Sludge volume load ( $\left.\mathrm{L}_{\mathrm{SV} / \mathrm{A}}\right)$ during the same test (Table 6).

Table 6. Average surface load and sludge volume load, and effluent water quality (SS, COD and $\mathrm{P}_{\text {tor }}$ ) during loading increase (Fig. 17).

\begin{tabular}{|c|c|c|c|c|c|c|c|c|c|c|c|c|c|c|}
\hline \multicolumn{3}{|c|}{ Loading } & \multicolumn{12}{|c|}{ Effluent quality } \\
\hline \multirow{3}{*}{$\begin{array}{c}\text { Hydr. } \\
\text { load } \\
\text { incr. } \\
\%\end{array}$} & \multirow{3}{*}{$\begin{array}{c}\begin{array}{c}\text { Surf. } \\
\text { load }\end{array} \\
\overline{\mathbf{x}} \\
\mathrm{m} \mathrm{h}^{-1}\end{array}$} & \multirow{3}{*}{$\begin{array}{c}\text { Sludge } \\
\text { vol. } \\
\text { load } \\
\bar{x} \\
\mathrm{~m} \mathrm{~h}^{-1}\end{array}$} & \multicolumn{4}{|c|}{ SS } & \multicolumn{4}{|c|}{ COD } & \multicolumn{4}{|c|}{$P_{\text {tot }}$} \\
\hline & & & \multicolumn{4}{|c|}{ Increase } & \multicolumn{4}{|c|}{ Increase } & \multicolumn{4}{|c|}{ Increase } \\
\hline & & & $\begin{array}{l}\overline{\mathrm{x}} \\
\%\end{array}$ & $\begin{array}{c}\bar{x} \\
\mathrm{mg} \mathrm{l}^{-1}\end{array}$ & s & $\underset{\mathrm{pcs}}{\mathrm{n}}$ & $\begin{array}{l}\overline{\mathrm{x}} \\
\%\end{array}$ & $\underset{\mathrm{mg} \mathrm{l}^{-1}}{\overline{\mathrm{x}}}$ & s & $\underset{\text { pcs }}{\mathrm{n}}$ & $\begin{array}{l}\bar{x} \\
\%\end{array}$ & $\underset{\mathrm{mg} \mathrm{l}^{-1}}{\overline{\mathrm{x}}}$ & $s$ & $\underset{\mathrm{pcs}}{\mathrm{n}}$ \\
\hline $\begin{array}{r}50 \\
85 \\
110 \\
150 \\
200\end{array}$ & $\begin{array}{l}1.7 \\
2.1 \\
2.4 \\
2.9 \\
3.4\end{array}$ & $\begin{array}{l}0.33 \\
0.40 \\
0.43 \\
0.47 \\
0.51\end{array}$ & $\begin{array}{r}20 \\
60 \\
60 \\
140 \\
160\end{array}$ & $\begin{array}{l}18 \\
19 \\
22 \\
24 \\
32\end{array}$ & $\begin{array}{r}12 \\
11 \\
11 \\
2\end{array}$ & $\begin{array}{r}25 \\
11 \\
13 \\
1 \\
2\end{array}$ & $\begin{array}{r}0 \\
0 \\
10 \\
30 \\
10\end{array}$ & $\begin{array}{l}61 \\
61 \\
60 \\
65 \\
65\end{array}$ & $\begin{array}{r}12 \\
12 \\
2 \\
23 \\
7\end{array}$ & $\begin{array}{r}27 \\
16 \\
16 \\
2 \\
4\end{array}$ & $\begin{array}{l}10 \\
10 \\
10 \\
60 \\
80\end{array}$ & $\begin{array}{l}1.0 \\
1.2 \\
1.1 \\
1.2 \\
1.7\end{array}$ & $\begin{array}{l}0.6 \\
0.8 \\
0.6 \\
0.8 \\
0.5\end{array}$ & $\begin{array}{l}26 \\
16 \\
16 \\
02 \\
04\end{array}$ \\
\hline
\end{tabular}

for the corresponding heights and the intermediate values were computed from these in a linear manner (Fig. 19).

An example of results from tests no. 1 and no. 6 (Table 7), Fig. 19 shows the values of $k_{1}$ as $1.3,2.5$, 3.3 , and 3.9 at $0.5 \mathrm{~m}$ intervals in the range of $200 \ldots 350 \mathrm{~cm}$. Using these values of $\mathrm{k}_{1}$ and assuming $\mathrm{k}_{2}=1.8$ constant, the velocity/concentration graphs of Fig. 18 are computed from the equation $\mathrm{v}=\mathrm{k}_{1} \mathrm{C}^{-\mathrm{k}_{2}}$.

When the model was calibrated by determining the settling velocities of the sludge blanket at different depths, the velocities obtained were then used as the settling velocities of new test runs in the verification of the model.

When performing the computation layer by layer, a change of sludge settling speed in the

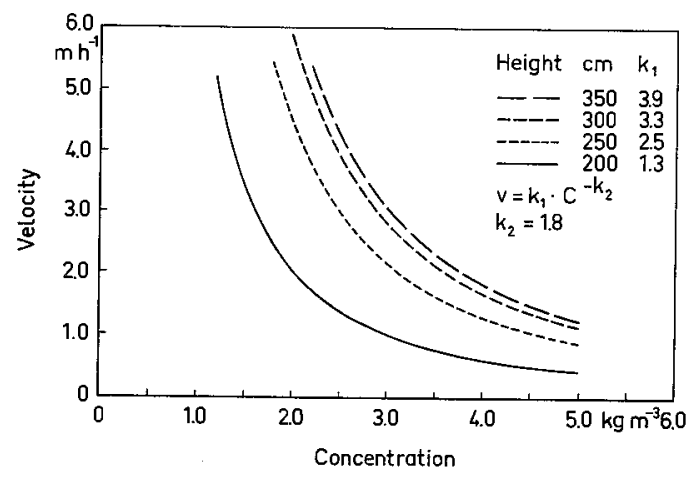

Fig. 18. Dependence of sludge settling velocity on solids concentration and sludge blanket height in tests on March 26, 1985. The settling velocity was approximated by coefficients of Fig. 19 . 

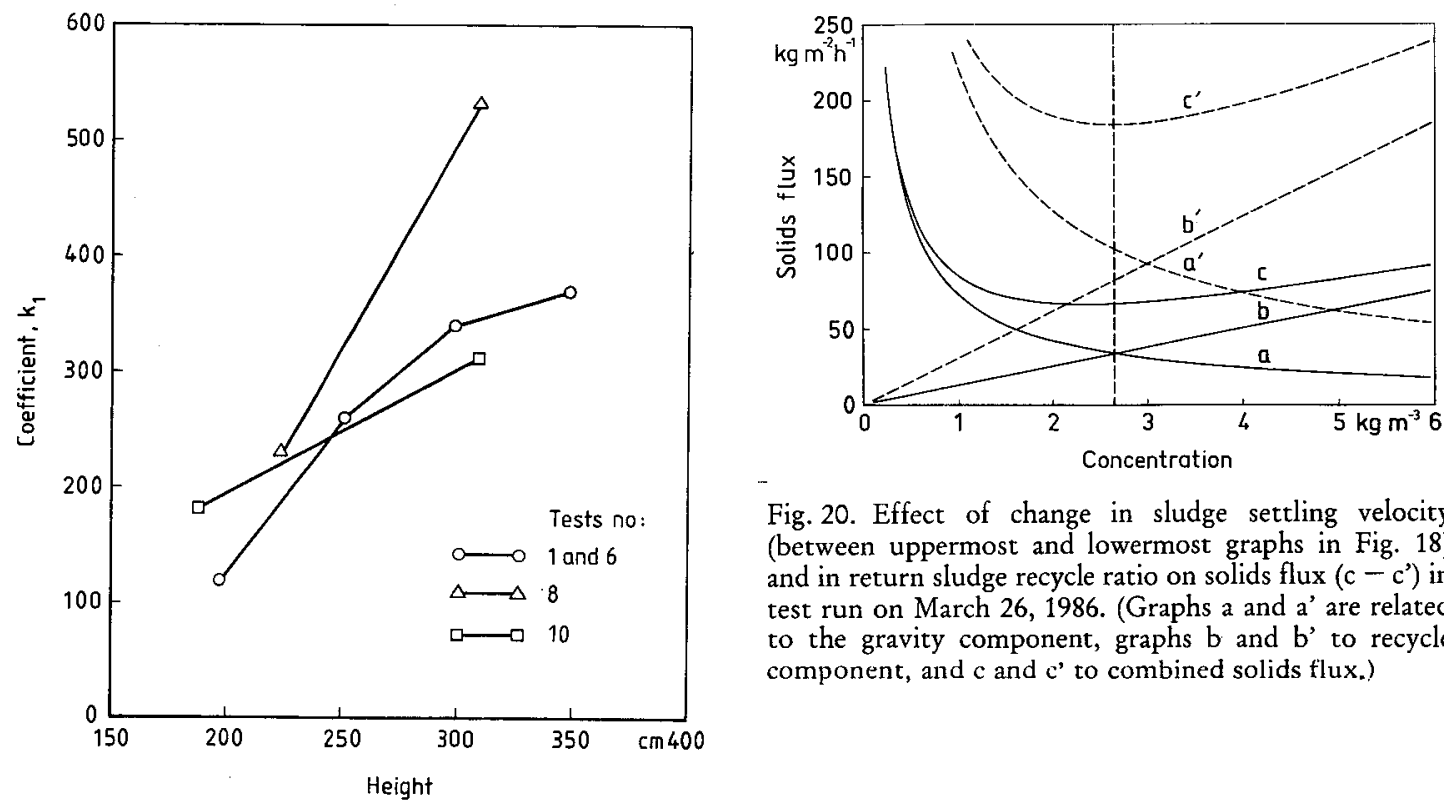

Fig. 20. Effect of change in sludge settling velocity (between uppermost and lowermost graphs in Fig. 18) and in return sludge recycle ratio on solids flux $\left(c-c^{\prime}\right)$ in test run on March 26, 1986. (Graphs a and a' are related to the gravity component, graphs $b$ and $b$ ' to recycle component, and $\mathrm{c}$ and $\mathrm{c}^{\prime}$ to combined solids flux.)

Fig. 19. Effect of sludge blanket height on sludge settling velocity coefficient $k_{1}$ in calibration of model (Table 7).

Table 7. Test run data in model calibration and verification tests together with computed sludge blanket heights. Sludge settling velocity coefficients $k_{1}$ are taken from Fig. 19.

\begin{tabular}{|c|c|c|c|c|c|c|c|c|c|c|}
\hline \multirow{3}{*}{$\begin{array}{l}\text { Test run } \\
\text { no. } \\
\text { Date }\end{array}$} & \multirow{3}{*}{$\begin{array}{l}\text { Flow } \\
Q_{E}+Q_{R}=Q_{0} \\
\mathrm{~m}^{3} \mathrm{~h}^{-1}\end{array}$} & \multicolumn{7}{|c|}{$\begin{array}{c}\text { Sludge blanket height } \\
\mathrm{H}=\mathrm{H}_{\mathrm{s}}^{19}-\mathrm{H}_{0}^{2)} \text { and } \mathrm{H}_{\mathrm{s}}, \mathrm{cm}\end{array}$} & \multirow{3}{*}{ 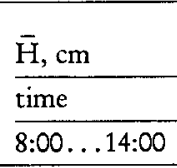 } & \multirow[t]{3}{*}{$\begin{array}{l}\text { Influent conc. } \\
\mathrm{C}_{0}, \mathrm{gl}^{-1}\end{array}$} \\
\hline & & \multicolumn{7}{|c|}{ time } & & \\
\hline & & $8: 00$ & $9: 00$ & $10: 00$ & $11: 00$ & $12: 00$ & $13: 00$ & $14: 00$ & & \\
\hline $\begin{array}{l}\mathrm{k}) \\
16.11 .-84\end{array}$ & $\begin{array}{l}25+13 \\
=38\end{array}$ & $\begin{array}{l}-9 \\
291\end{array}$ & $\begin{array}{l}-7 \\
293\end{array}$ & $\begin{array}{l}+5 \\
\left.350^{3}\right)\end{array}$ & $\begin{array}{l}+5 \\
350^{3)}\end{array}$ & $\begin{array}{l}+5 \\
350^{3)}\end{array}$ & +6 & +15 & $(7)^{3)}$ & \\
\hline $\begin{array}{l}2 \\
21.11 .-84\end{array}$ & $\begin{array}{l}20+10 \\
=30\end{array}$ & $\begin{array}{l}+4 \\
289\end{array}$ & $\begin{array}{l}+4 \\
290\end{array}$ & $\begin{array}{l}+16 \\
316\end{array}$ & $\begin{array}{l}+0 \\
\left.350^{3}\right)\end{array}$ & $\begin{array}{l}+0 \\
350^{3)}\end{array}$ & $\begin{array}{l}-13 \\
328\end{array}$ & $\begin{array}{l}-24 \\
296\end{array}$ & $(9)^{3)}$ & $2.5 \ldots .3 .1$ \\
\hline $\begin{array}{l}3 \\
26.11 .-84\end{array}$ & $\begin{array}{l}21+10 \\
=31\end{array}$ & $\begin{array}{l}-17 \\
253\end{array}$ & $\begin{array}{l}-24 \\
251\end{array}$ & $\begin{array}{l}-21 \\
274\end{array}$ & $\begin{array}{l}-38 \\
307\end{array}$ & $\begin{array}{l}-32 \\
313\end{array}$ & $\begin{array}{l}-28 \\
292\end{array}$ & $\begin{array}{l}-34 \\
261\end{array}$ & 28 & $2.2 \ldots 2.7$ \\
\hline $\begin{array}{l}4 \\
20.03 .-86\end{array}$ & $\begin{array}{l}20+10 \\
=30\end{array}$ & & $\begin{array}{l}+14 \\
247\end{array}$ & $\begin{array}{l}+14 \\
266\end{array}$ & $\begin{array}{l}+36 \\
324\end{array}$ & $\begin{array}{l}+55 \\
350^{3)}\end{array}$ & $\begin{array}{l}+28 \\
307\end{array}$ & $\begin{array}{l}+36 \\
283\end{array}$ & $(31)^{3)}$ & $2.4 \ldots 2.7$ \\
\hline $\begin{array}{l}5 \\
26.03 .-86\end{array}$ & $\begin{array}{l}25+13 \\
=38\end{array}$ & & $\begin{array}{l}+35 \\
223\end{array}$ & $\begin{array}{l}+12 \\
254\end{array}$ & $\begin{array}{l}-14 \\
284\end{array}$ & $\begin{array}{l}-13 \\
289\end{array}$ & $\begin{array}{l}+12 \\
272\end{array}$ & $\begin{array}{l}+35 \\
245\end{array}$ & 20 & $1.9 \ldots 2.8$ \\
\hline $\begin{array}{l}6^{\mathrm{k})} \\
16.06 .-86\end{array}$ & $\begin{array}{l}20+20 \\
=40\end{array}$ & & $\begin{array}{l}+3 \\
200\end{array}$ & $\begin{array}{l}+11 \\
226\end{array}$ & $\begin{array}{l}-5 \\
247\end{array}$ & $\begin{array}{l}-2 \\
250\end{array}$ & $\begin{array}{l}+12 \\
237\end{array}$ & $\begin{array}{l}+10 \\
212\end{array}$ & 7 & $1.8 \ldots 2.0$ \\
\hline $\begin{array}{l}7 \\
17.06 .-86\end{array}$ & $\begin{array}{l}20+5 \\
=25\end{array}$ & & $\begin{array}{l}+4 \\
204\end{array}$ & $\begin{array}{l}-19 \\
223\end{array}$ & $\begin{array}{l}-28 \\
240\end{array}$ & $\begin{array}{l}-31 \\
241\end{array}$ & $\begin{array}{l}-33 \\
229\end{array}$ & $\begin{array}{l}-1 \\
209\end{array}$ & 19 & $1.5 \ldots 1.9$ \\
\hline $\begin{array}{l}8^{\mathrm{k})} \\
21.03 .-86\end{array}$ & $\begin{array}{l}20+30 \\
=50\end{array}$ & & $\begin{array}{l}+5 \\
230\end{array}$ & $\begin{array}{l}+11 \\
266\end{array}$ & $\begin{array}{l}+12 \\
312\end{array}$ & $\begin{array}{l}+11 \\
321\end{array}$ & $\begin{array}{l}-16 \\
272\end{array}$ & $\begin{array}{l}-4 \\
241\end{array}$ & 10 & \\
\hline $\begin{array}{l}9 \\
07.04 .-86\end{array}$ & $\begin{array}{l}22.5+27.5 \\
=50\end{array}$ & & $\begin{array}{l}+2 \\
215\end{array}$ & $\begin{array}{l}+25 \\
253\end{array}$ & $\begin{array}{l}+12 \\
275\end{array}$ & $\begin{array}{l}+3 \\
278\end{array}$ & $\begin{array}{l}+14 \\
257\end{array}$ & $\begin{array}{l}+8 \\
226\end{array}$ & 11 & $2.3 \ldots 2.5$ \\
\hline $\begin{array}{l}10^{\mathrm{k})} \\
25.03 .-86\end{array}$ & $\begin{array}{l}25+25 \\
=50\end{array}$ & & $\begin{array}{l}+1 \\
189 \\
\end{array}$ & $\begin{array}{l}+14 \\
254\end{array}$ & $\begin{array}{l}-5 \\
300 \\
\end{array}$ & $\begin{array}{l}-14 \\
296\end{array}$ & $\begin{array}{l}+10 \\
272\end{array}$ & $\begin{array}{l}+29 \\
233 \\
\end{array}$ & 12 & \\
\hline
\end{tabular}


model also changes the solids flux simultaneously (Fig. 20) and its distribution to above and below the feed point.

Sludge profile concentration in the upper part (Fig. 21) has been stabilized in calibration by reducing the diffusion coefficient $(\mathrm{D})$ of equation (13) if the profile was considered too lean in concentration, or alternatively, by increasing the coefficient value if excessive growth of concentration was observed in relation to the measurement results.
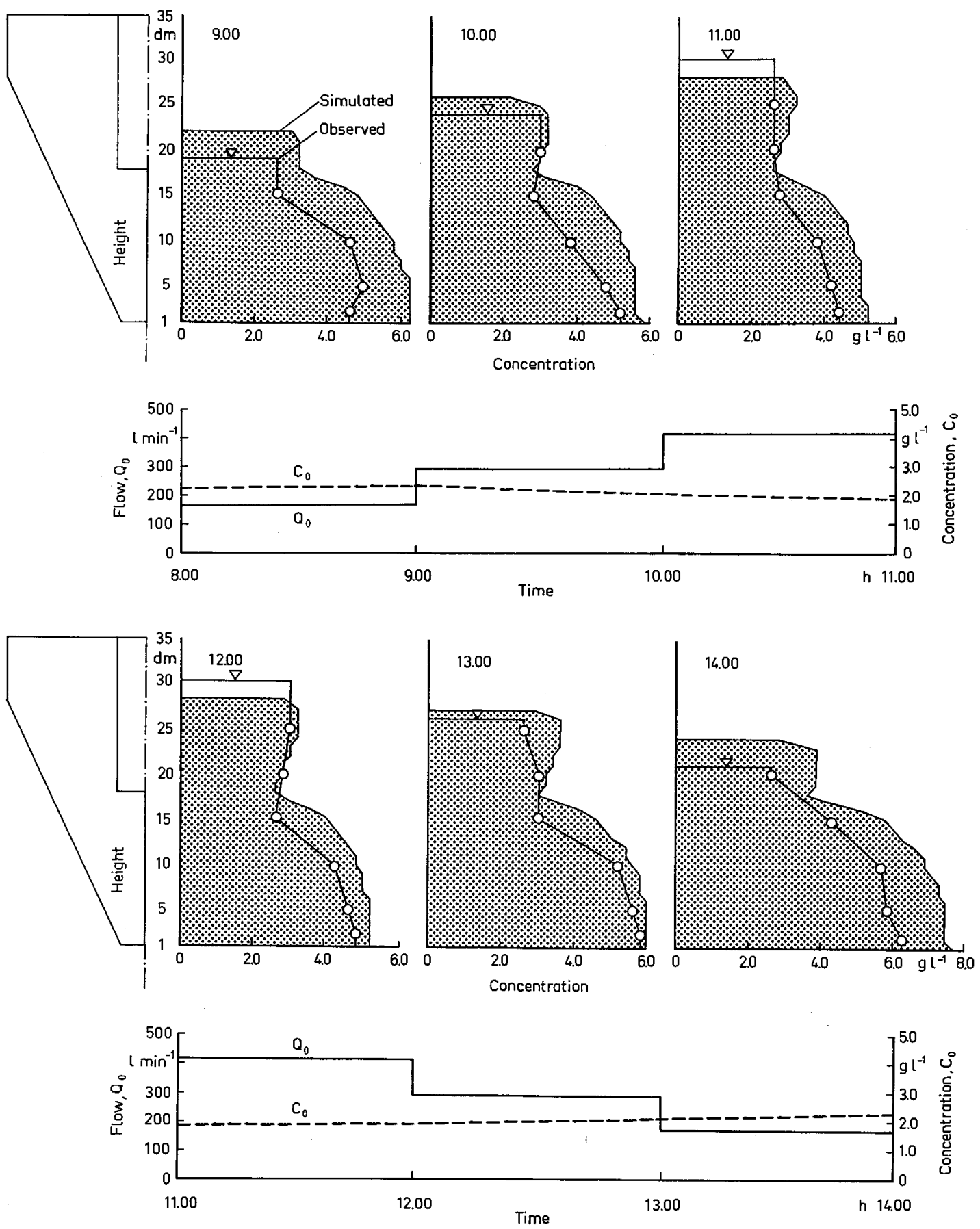

Fig. 21. Changes in clarifier sludge blanket profile due to load changes in test run on March 26, 1986. 
The model was calibrated by test runs 1 and 6 (Table 7). Height differences in the simulated and measured sludge blanket level varied in calibration runs (from 08:00 to 14:00), in printouts at one hour intervals' between $-9 \mathrm{~cm}$ and $+15 \mathrm{~cm}$, and at 12:00 stayed between $-2 \mathrm{~cm}$ and $+5 \mathrm{~cm}$ in the upper position of the sludge blanket top level, which is a crucial operating factor of the clarifier efficiency. Calibration was performed using the aforementioned test runs 1 and 6 because these runs together cover the height variations in sludge blanket top level in verification data.

The model calibration was performed at two levels of accuracy. First, the model calibrated as described above, was verified by test runs $2 \ldots 5$ and 7 (Table 7). Height differences between the simulated and observed sludge blanket levels in the simulation runs were approximately $(9)^{*} \ldots 31 \mathrm{~cm}$ and at 12:00 the maximum height of sludge blanket was, on the average (26) ...33 cm (Fig. 22). The signs of differences were systematically positive or negative according to whether the settling velocities in the calibration run were too low or too high compared to velocities reported in previous verification runs. Next, the calibration of the model with test run 1 and its verification five days later in test run 2 , proved to be significantly more accurate, attaining an accuracy level higher than that of test run 3, which was performed five days later than test run 2. ("The simulated sludge blanket height exceeded the upper limit of 350 cm.)

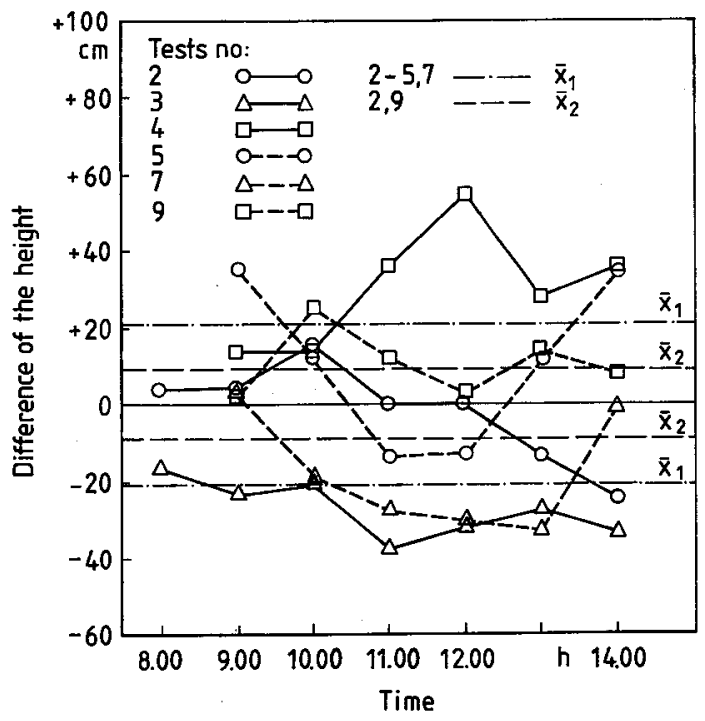

Fig. 22. Difference between simulated sludge blanket height and observed height in model verification run of test plant (Table 7 , runs $2 \ldots 5$ and 7 ).
The accuracy was also improved by maintaining the sludge level height in both runs within the same variation range (about $290 \ldots 350 \mathrm{~cm}$ ).

The model calibration using maximum flow and high return sludge recycle ratios (Table 7 , run 8) differs distinctly from the results described above. Coefficient $\mathrm{k}_{1}$ of sludge settling velocity (Fig. 19, graph 8 ) is $10 . .70 \%$ larger than previously. With diminishing recycle ratio (Table 7 , run 10 ), the values of coefficient $k_{1}$ drop again to the earlier level (Fig. 19, graph 10).

In verification run 9 , which was performed in compliance with calibration run 8 , the simulation accuracy of sludge blanket height was $11 \mathrm{~cm}$.

Summarizing the foregoing calibration and verification data, it can noted that the accuracy of verification results is decisively dependent on the sludge settling velocity used. Furthermore, the settling velocity is dependent on the sludge quality. In addition, the recycling of return sludge has an effect on the sludge settling velocity. For the whole data, the accuracy of verification runs (runs $2 \ldots 5$ and 7) has been, on the average, (21) $\ldots 23 \mathrm{~cm}$ and in the upper position of the sludge blanket top level (at 12:00) (26) ..25 cm. The accuracy of results in successive runs (runs 2 and 9) was clearly better. The corresponding values for these runs are (9) $\ldots 11 \mathrm{~cm}$ and $(0) . .3 \mathrm{~cm}$.

Inflow $\left(Q_{0}\right)$ to the clarifier in verification runs (runs 2..5 and 7) varied during load increases in the range of $10 \ldots 38 \mathrm{~m}^{3} \mathrm{~h}^{-1}$, and the proportion of return sludge flow $\left(Q_{R}\right)$ was $5 \ldots 13 \mathrm{~m}^{3} \mathrm{~h}^{-1}$. The recycle ratio $(R)$ of clarifier effluent flow (that is, from inflow of treatment plant) was $25 . .50 \%$.

The corresponding flows in successive runs (runs 2 and 9) were $Q_{0}=10 \ldots 50 \mathrm{~m}^{3} \mathrm{~h}^{-1}$ and $\mathrm{Q}_{\mathrm{R}}=$ $5 . .27 .5 \mathrm{~m}^{3} \mathrm{~h}^{-1}$ while the recycle ratio was $\mathrm{R}=$ $50 . .125 \%$. Solids concentration in the influent to the clarifier varied in the range of $\mathrm{C}_{0}=$ $1.5 \ldots 3.1 \mathrm{~g} \mathrm{l}^{-1}$ (runs $2 \ldots .5$ and 7 ) and $2.3 \ldots 3.1$ $\mathrm{g} \mathrm{l}^{-1}$ (runs 2 and 9 ).

\subsection{Model sensitivity}

The structure-dependent sensitivity of the model was estimated by computing the sensitivity coefficient (S) from the following equation (Water Association 1986)

$\mathrm{S}(\mathrm{t})=(\Delta \mathrm{x} / \mathrm{x}) /(\Delta \mathrm{p} / \mathrm{p})$

The input parameters (p) of the equation were the inflow $\left(Q_{0}\right)$ to the clarifier, influent solids concentration $\left(\mathrm{C}_{0}\right)$, sludge recycle flow $\left(\mathrm{Q}_{\mathrm{R}}\right)$, and 
sludge settling velocity coefficient $\left(\mathrm{k}_{1}\right)$. Deviation $(\triangle \mathrm{p})$ of the input parameter was $\pm 5 \%$ and with velocity coefficient $\pm 10 \%$, too. The sludge blanket height and its respective changes $(\Delta x)$ were consistently treated as the output parameter (x) of the model.

When the inflow $\left(Q_{0}\right)$ to the clarifier was changed at each step of the flow "staircase" by $\pm 5 \%$, the sensitivity increased gradually over a period of $6 \ldots 7 \mathrm{~h}$ from a level of $0.1 \ldots 0.2$ to a level of about 0.7 (Fig. 23a). Correspondingly, changes in influent solids concentration $\left(\mathrm{C}_{0}\right)$ to the clarifier by $\pm 5 \%$ drive the sensitivity of the model gradually towards 1 in about $4 \ldots 5 \mathrm{~h}$ from the beginning of the process (Fig. 23b).

The delay in approaching the value 1 in sensitivity is caused by the conical shape of the clarifier because the response of the sludge blanket in the conical part of the clarifier is stronger than in the upper part of the clarifier cylinder.

Changes of $\pm 5 \%$ in the sludge return flow $\left(Q_{R}\right)$ do not invoke a response resulting in a change of the sludge blanket (Fig. 23c).

Changes in sludge settling velocity $(\Delta \mathrm{p}$ in Eq. 18) have been taken as $\pm 5 \%$ and $\pm 10 \%$ deviations from the values of coefficient $k_{1}$, each of which have been determined in the steady state of the process at a certain height of the sludge blanket. Changing the coefficient is relative to a corresponding change in the settling velocity.

The model sensitivity (term $S$ in Eq. 18) changes during a time period of $4 \ldots 5$ hours from \pm 0.1 to \pm 0.5 for a deviation of $\pm 5 \%$ (Fig. 24a) and for a deviation of $\pm 10 \%$ during the same time to \pm 1.0 (Fig. 24b). A higher settling velocity reduces the sludge blanket height, and correspondingly, a slower velocity increases the height.

Acute swings in the sensitivity (Figs. 23a, b, c) are caused by the abrupt changes of model input parameters. In practical terms, e.g., the variations of flow occur at a certain delay, which is caused by, for instance, weirs in the aeration basin. This effect is not included in the model but instead the changes of model parameters are allowed to have the character of a step function without delay.

In summary it can be noted that the tested changes of sensitivity as a function of time in the model are logical to their character. Sensitivities approaching a value of 1 indicate a linear relationship between the input and output. The acute swings could possibly be attenuated by complementing the model with delays of input parameter changes and by modifying the computation algorithm into a more stable form. However, the sensitivity is generally calculated only for constant parameters. Due to the transients in computation, the sludge blanket heights were rechecked.

\subsection{Model results}

The model was used for simulating variations in the loading of a clarifier in four different ways so that each input parameter (flow, solids concentration, sludge recycle ratio) was altered separately and the other parameters were maintained constant. This method provided the experimental data for computing the effect of clarifier inflow, its solids concentration, and sludge recycle ratio on height and concentration changes in the sludge blanket. The hydraulic load and solids load of the clarifier are later treated in conjunction with clarifier surface load and sludge surface load.

The first case of model test runs (Fig. 25) simulated a flow, whose increasing volume was related to a decreasing solids concentration so that the solids load rate (as well as the sludge surface load) were constant during the test (from 08:00 to 14:00). The flow varied during the test so that the flow peak simulating a stepwise increase of flow (at 09:00 and 10:00) and corresponding decrease (at 12:00 and 13:00) were increased or decreased respectively with an equal proportion (\%) compared to the reference run on June 16, 1986. Thus, the hydraulic surface load rate of the clarifier varied from run to run (with the exception of one run, also from 08:00 to 14:00).

When the sludge surface load was held constant but the hydraulic surface load was increased, the sludge blanket top level decreased with an increase in the hydraulic surface load (Fig. 25). This is because the solids concentration decreases in the influent and simultaneously in the sludge blanket of the clarifier, which further appreciably increases the sludge settling velocity. Further, the increased settling velocity strongly depresses the sludge blanket height. For instance, the sludge blanket concentration was at 08:00 (that is, before the load change) at the bottom of the clarifier in the order of $5 . .6 \mathrm{~g}^{-1}$ while at $12: 00$ it was only in the order of $1 \ldots .2 \mathrm{~g} \mathrm{l}^{-1}$. The settling velocity was then increased 5. .6 -fold from its initial value (Fig. 18).

In the second case, a peak flow caused by wastewater loading was simulated. In this case, the wastewater solids concentration was constant during the changes in loading but the inflow (that is, the hydraulic surface load) varied in the same manner as described above (Fig. 26). The flow increase caused an equivalent increase in the solids load (sludge surface load). With an increasing 

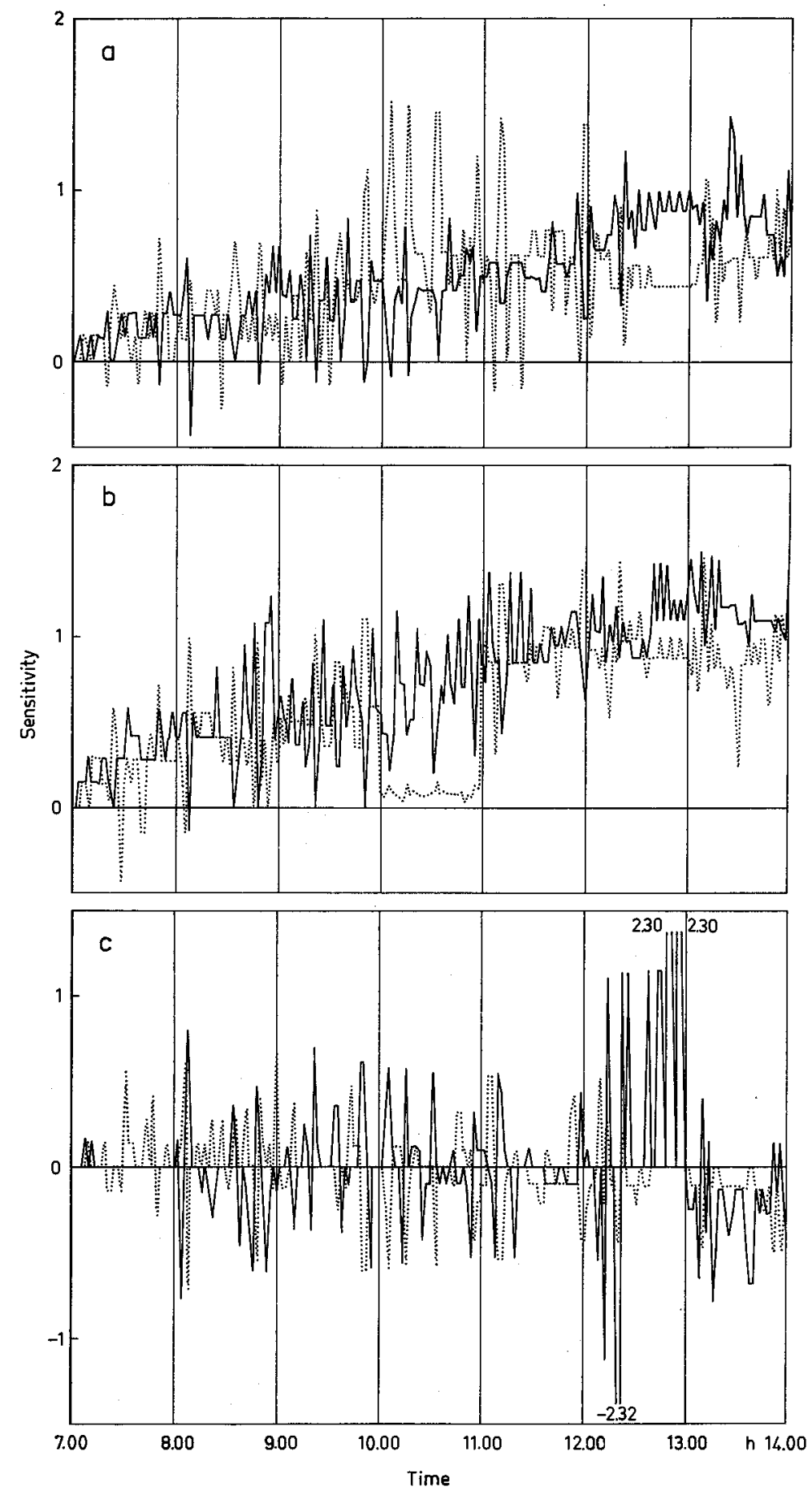

Fig. 23. Model sensitivity to changes in a) inflow to clarifier $\left(Q_{0}\right)$, b) solids concentration $\left(\mathrm{C}_{0}\right)$, and $\mathrm{c}$ ) return sludge flow $\left(\mathrm{C}_{R}\right)$ by $\pm 5 \%$. 

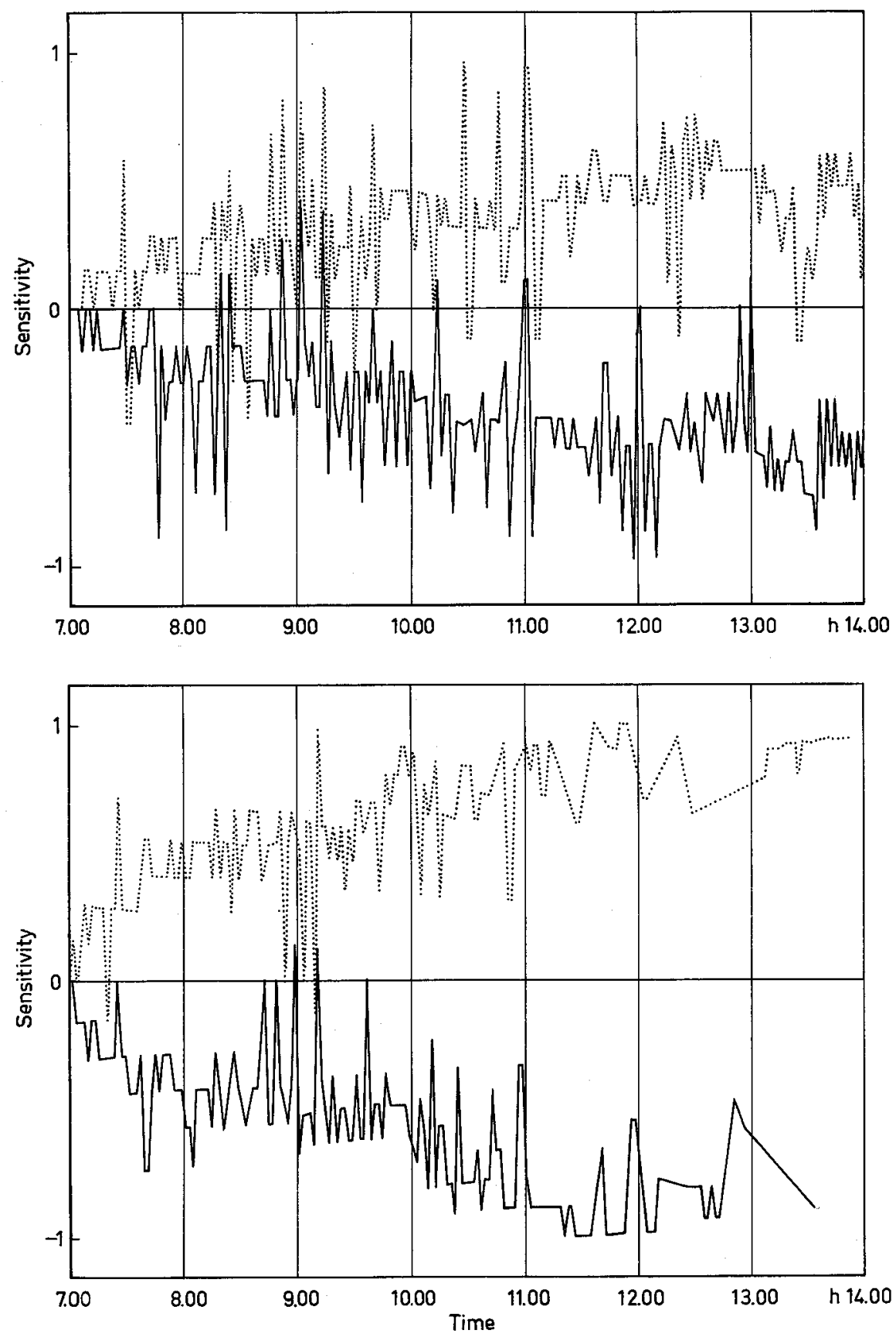

Fig. 24. Model sensitivity to changes in sludge settling velocity coefficient $k_{1}$. a) changed by $\pm 5 \%$ and $b$ ) changed by $\pm 10 \%$. 
loading, the sludge blanket height increased in relation to the reference run height, and conversely, decreased at a diminishing loading.

In the third case (Fig. 27), the influent solids concentration was changed relative to the reference run value. During the run (from 08:00 to 14:00), the concentration varied so that it first decreased when the loading was increasing in the morning but then recovered to approximately the initial level when the loading was decreasing in the afternoon. The influent solids concentration (as well as the flow) were changed by altering the concentration levels in the reference run by the same proportion (\%) during the entire run (from 08:00 to 14:00). The flow and other input
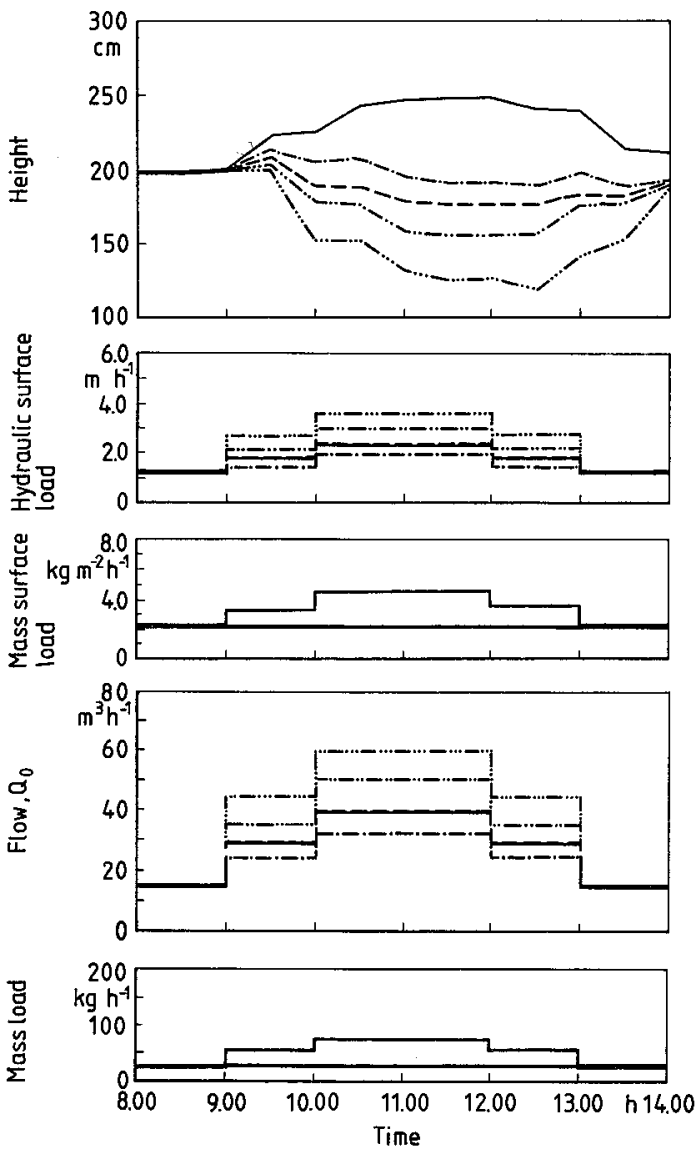

Maximum hydraulic surface load

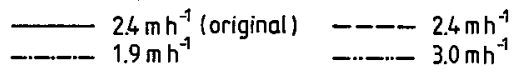

$$
\begin{aligned}
& \text {-...... } 3.6 \mathrm{mh}^{-1}
\end{aligned}
$$

Fig. 25. Effect of hydraulic surface load on the sludge blanket height in a clarifier with a constant sludge surface load. parameters were maintained constant at the same levels as in the reference run.

An increase in the influent solids concentration increased the solids load (and the surface load) as well as the sludge blanket height in relation to the reference run values. Correspondingly, a decrease in the influent solids concentration decreased the sludge blanket height (Fig. 27).

In the fourth case (Fig. 28), the effect of sludge recycling on the sludge blanket profile was investigated. The recycle ratio was increased (to $100 \%$ ) in the reference run and both increased (to $150 \%$ ) and decreased (to $50 \%$ and to $25 \%$ ) in different simulation runs. The other input parameters were maintained constant at the reference
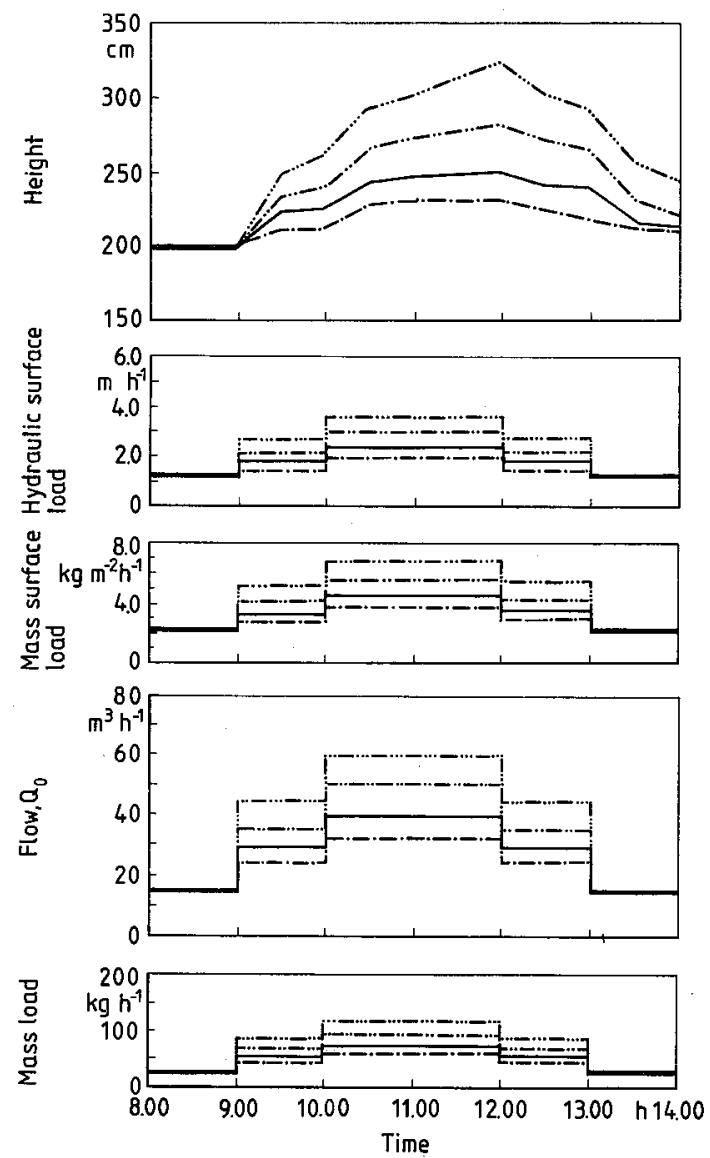

Maximum mass surface load

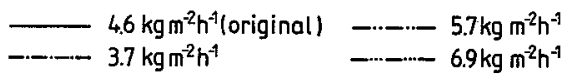

Fig. 26. Effect of sludge surface load (and the hydraulic surface load) in a clarifier on the sludge blanket height. 
run levels.

Changes in sludge recycle ratio are not expressly visible in the sludge blanket height in relation to the reference run. By contrast, the sludge blanket profile became leaner, which indicates lessened solids concentration in the sludge blanket for an increase in recycle flow, and correspondingly, a concentration increase for a decrease in recycle flow.

When the second and third case, in both of which the sludge mass load the sludge surface load increase, although for different reasons, are compared to each other, changes in the sludge blanket height can also be noted (Fig. 29).

The points of graph a in Fig. 29 are obtained using a constant inflow while the inflow varies for graph b. It can be seen that influent solids concentration for graph $a$ is lower than that of graph $b$ to the left of the intersection and higher to the right (the same also applies to the concentrations in the sludge blanket). The sludge settling velocities are higher in a lower solids concentration, which also depresses the sludge blanket height. Consequently, the sludge surface load does not alone determine the sludge blanket height but it is also influenced by the influent concentration.
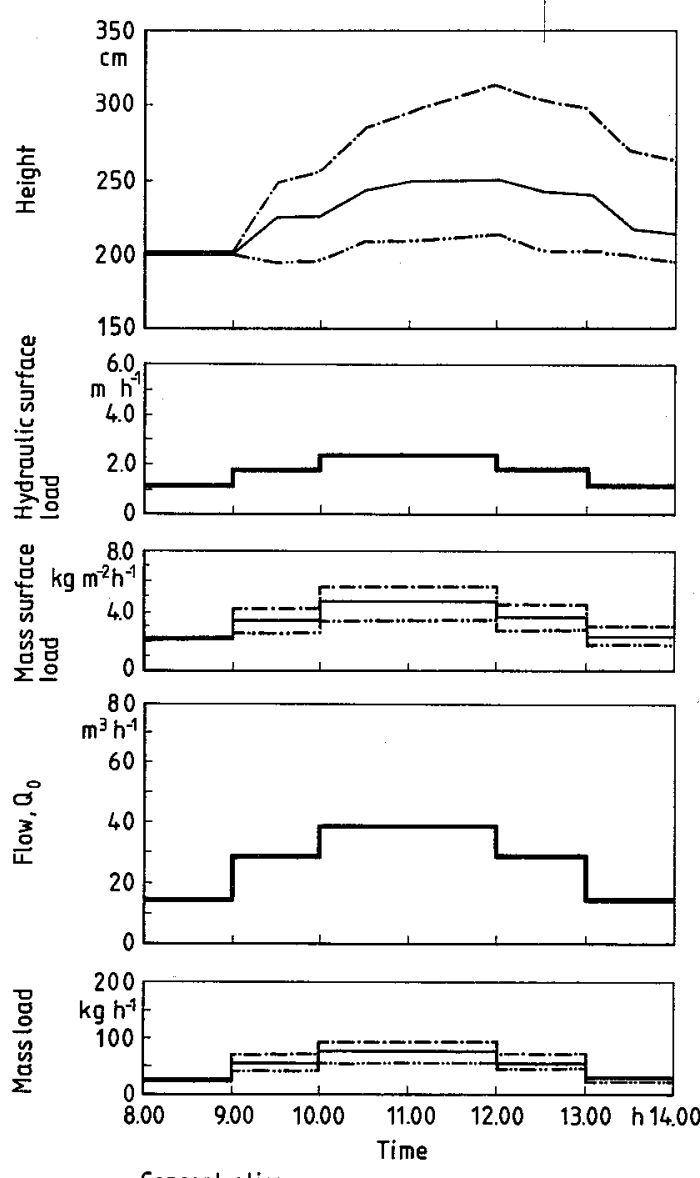

Concentration

$$
\begin{aligned}
& c_{0}=1.8-2.0 \mathrm{gl}^{-1} \\
& \text { loriginal) }
\end{aligned}
$$

Fig. 27. Effect of influent solids concentration (or solids load) in a clarifier on the sludge blanket height.
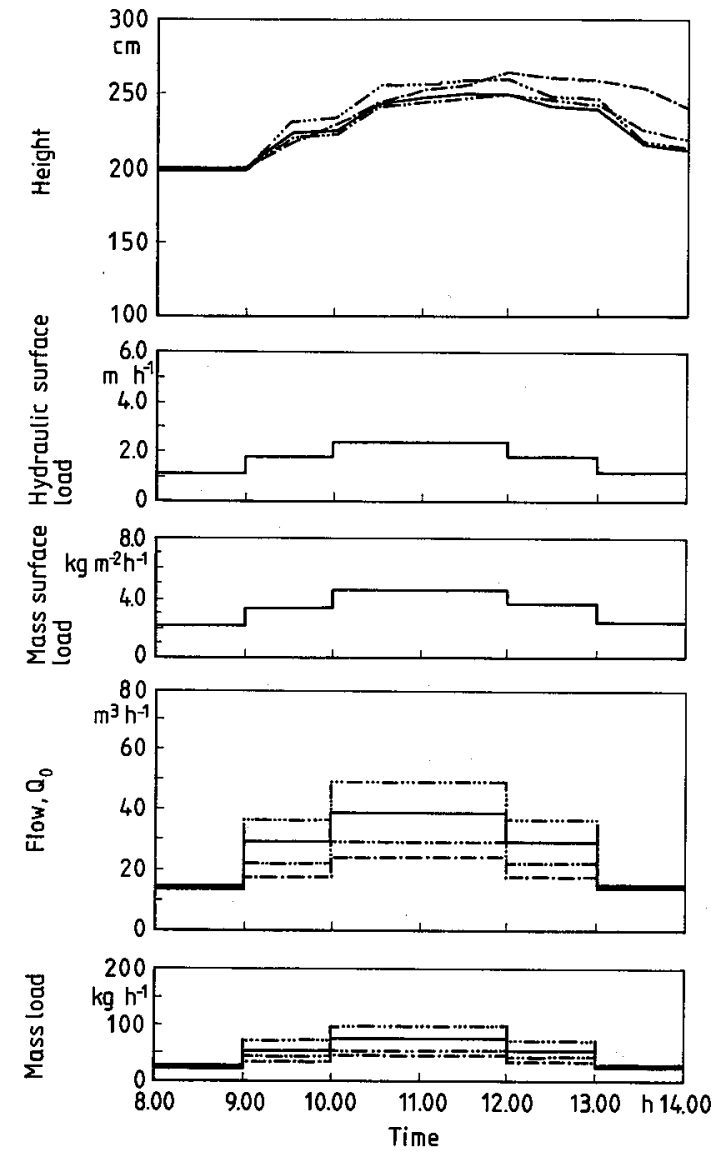

Sludge return

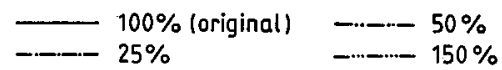

Fig. 28. Effect of sludge recycling on the sludge blanket height in a clarifier. 


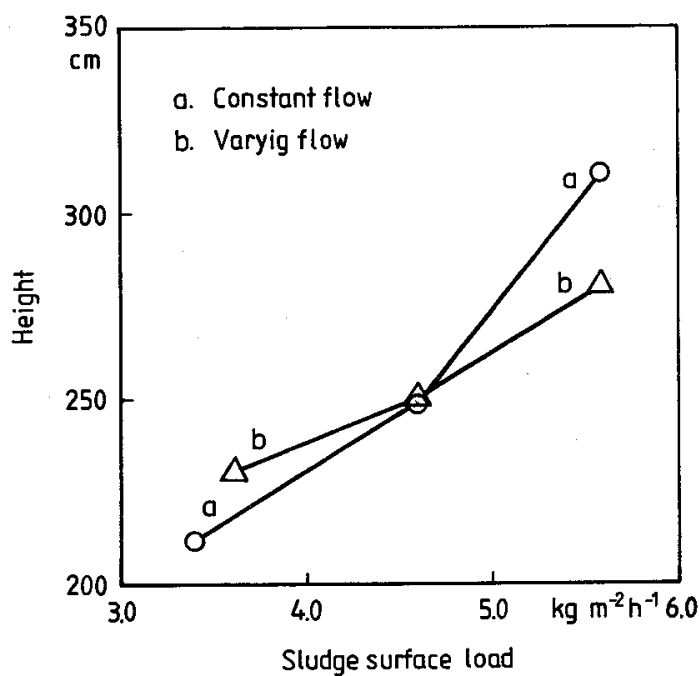

Fig. 29. Dependence of the maximum height of sludge blanket in a clarifier on (highest) runtime sludge surface load at a) constant flow and b) varying flow.

\section{SUMMARY OF RESULTS AND CONCLUSIONS}

\subsection{Modelling and experimental conditions}

Test runs for model calibration and verification were performed in two phases. Runs performed in 1984 were based on taking zone settling velocities measured from the cylinder tests as the sludge settling velocities. Because the model did not perform satisfactorily at these velocities, new test runs were performed in 1986. In conjunction with these tests, the sludge settling velocity was determined using a specifically developed in-situ method. The calibration and verification of the model indicated that sludge settling velocity in the sludge blanket varies, e.g., at different times of the year.

Consequently, in order to improve the accuracy of modelling, test runs should be performed in test series of several days under constant conditions in regard to the settling velocity. These test series should be run for different settling velocity conditions, such as different seasons of the year. After this, each test series with the same settling velocity should be calibrated separately.

The approximation of sludge settling velocity can further be improved, but regarding the approximation method used, it must be noted that if the variation range of sludge blanket top level differs from the levels of the calibration run, the model extrapolates the velocity factor values linearly. If the deviation is significant, the linear extrapolation of the velocity factor may also cause a discernible difference in comparison with the observed values. Thus, the aforementioned test series should also be run so that the sludge blanket top levels in different test runs are allowed to vary approximately within the same range of levels.

\subsection{Determination of sludge settling velocity}

In the model proposed by Tracy and Keinath (1973), the sludge settling velocity has been defined in cylinder tests as the zone settling velocity. According to the reference literature, this velocity has been used as the settling velocity in a model simulating sludge settling and thickening. The aforementioned model simulated a clarifier in which sludge was "raining" onto the sludge blanket surface, i.e., the surface was always located below the sludge feed point. For simulation, the sludge blanket was divided into ten layers, and in the computation of concentration changes in each layer, the zone settling velocity was used as sludge settling velocity.

The model developed in this study, which has been derived from the model proposed by Tracy and Keinath, was preliminarily tested using zone settling velocities obtained from cylinder tests. However, the results were not satisfactory because the new model differed so extensively from the model of Tracy and Keinath, which describes a relatively stable sludge blanket. In the new model, sludge is generally fed into the interior of the blanket. The concentrations at the upper part of the blanket are remarkably lower than the concentration of the lower part, which in the new model causes sensitive changes in the settling velocity in relation to the concentration. In addition, the model developed takes into account the fact that the sludge settling velocity increases in relation to the sludge blanket depth.

Hence, the sludge settling velocities were determined for the new model directly from concentration changes measured in the clarifier at different depths of the sludge blanket when the clarifier was operated under constant conditions. At these velocities, the model performed with satisfactory accuracy. The determined velocities were then as high as twofold compared to the 
cylinder test results.

The velocity differences were primarily caused by the fact that the average particle size deeper in the sludge blanket is larger than in the upper layers and that the settling velocity of a larger particle is greater than that of a small one (as stated by the Stokes' law). This distribution of particle sizes was not determined in the study but instead it was approximated at the sludge blanket height which was resulted in a sufficient accuracy in regard to the behaviour of the model.

The zone settling velocity is related to the settling velocity of sludge blanket surface in the test cylinder. After initial fill-up, a rather distinct sludge-to-water interface settling at a constant velocity is relatively quickly formed in the cylinder. The phenomenon cannot be assigned to the settling of individual particles but the sludge blanket surface rather sinks as a "solid felt", which during the settling process is permeable to water. Thus, the zone settling is dependent, among other factors, on the permeability of the described feltlike surface of the blanket. Individual particles with higher settling velocities are observable both above as well as below the blanket. The latter will naturally land on the blanket upper surface.

For obvious reasons, the zone settling velocities determined from cylinder test are not related sufficiently accurately to the sludge settling velocity as regards to the model. Equally, the theory proposed by Kynch (1952) that sludge settling velocity is only dependent on its concentration remains excessively inaccurate to be applied in the model. Additional factors influencing sludge settling velocity include, i.a., particle size which has been approximated in this study by the sludge blanket thickness.

Therefore, in the developed model and in other models of similar dynamic character, the sludge settling velocity should be determined directly in the clarifier by taking into account velocity-related factors, such as sludge quality and sludge blanket thickness. This procedure is extensively facilitated by modern measurement equipment.

\subsection{Clarifier efficiency and design principles}

Results obtained from the loading tests of the test plant indicate that the increase of sludge surface load and hydraulic surface load $\left(2 \ldots 2.5 \times Q_{\text {dim }}\right)$ increased, for instance, the effluent solids concentration relative to the design values almost in a linear ratio to the load increase (solids increase
$75 \ldots 150 \%)$. The test runs were arranged so that the maximum height of sludge blanket did not reach a level which would have allowed sludge loss from the clarifier.

The loading response of the test treatment plant also indicated the solids imported by the increase in load rate is accumulated in upper part of the clarifier. Consequently, the upper part volume can be dimensioned to receive the excess solids caused by load changes.

Clarifier efficiency and related factors are also evaluated with help of the developed model. Although the solids-retaining efficiency of the clarifier decreases at higher loads, the clarifier loses significant capacity only when the growth of sludge blanket top level approaches close (to $0.2 \ldots 0.3 \mathrm{~m}$ ) to the clarifier liquid surface leads to a continual solids loss with the effluent.

According to the results from the model, the efficiency and capacity of the clarifier depend mostly on the influent solids load to the clarifier, available sludge storage capacity, and sludge settling velocity in the clarifier. A low sludge concentration in influent also decreases the solids concentration of the sludge blanket and increases the settling velocities of sludge and sludge blanket top level.

The design guidelines used in Finland do not explicitly consider load peaks. Instead, the capacity required for the peaks is separately taken into account in the selection of design values. The design of a plant in compliance with the instructions must be dimensioned so that it is capable of handling a flow of twice the design value without major difficulties. The dimensioning of a vertical clarifier is performed according to the surface loading and sludge volume load. In the design calculations, the sludge concentration of influent to the clarifier is increased by $1 . .2$ $\mathrm{kg} \mathrm{m}^{-3}$ compared to the concentration in aeration. For normal municipal wastewaters, a sludge index of $75 \ldots 100$ is used, depending on the sludge load (National Board of Waters 1976, 1982).

According to the simulation examples, a doubled flow at a constant solids concentration increases the top level of the sludge blanket approximately in equal proportion $(0.9 \ldots 1.0 \mathrm{~m})$ to an increase of $25 \%$ in the solids concentration of influent to the clarifier. Together the doubled flow and increase of solids concentration represent a dimensioning situation not generally encountered in practice. This is because the flow increase is either caused by increase of wastewater quantity or by stormfall waters so that the solids concentration in influent to the clarifier does not change in principle. According to the simulation example, a doubled 
flow decreases the top level of the sludge blanket and thus increases the clarifier capacity. Both effects are caused by sludge transfer from the aeration basin to the clarifier and from the decrease in the sludge concentration of influent.

On this basis, it can be inferred that the dimensioning and design guidelines for clarifiers should be detailed to comply in their principles with practical dimensioning situations. By decreasing the solids concentration of influent to the clarifier, sludge settling velocity and clarifier capacity can be increased.

\subsection{Proposal for further investigations}

Simulation studies in wastewater treatment intended to improve, for instance, process control and operating systems, are actively conducted in Finland. Clarification as a subprocess of wastewater treatment forms a crucial focal point.

Generally, models can be used for estimating the effect of different parameters in a dynamic process such as clarification. Arranging compatible test conditions may, in practice, often be impossible in regard to the wastewater quantity, quality, or scale of experiment. Thus, modelling and model development of clarification should be continued in order to provide facilities for functional improvement of the model. Development of a vertical clarifier model should be pursued along two parallel lines, namely by further improving the modelling of the vertical clarifier, and secondly, by utilizing the model results in preparation of dimensioning and design instructions.

Model investigations on a vertical clarifier can be further improved by complementing the model with an aeration basin, which provides possibilities to evaluate, for instance, the interaction of aeration with clarification as well as the interdependence of different basin volumes. The in-situ method for determination of sludge settling velocity can also be improved. In order to simplify measurement and to speed computation of results, the model can be complemented with a supplementary program. Furthermore, extended analysis of sludge settling velocity finds an impetus, especially in conjunction with poorly settling sludges. Research in the modelling of the vertical clarifier would also gain from investigations into the importance of constant load feed into the inner volume of the sludge blanket to the effluent water quality in order to optimize the feed. Equally, the possibility of improving the settling result with intermediate chemical treatment before settling should also be investigated.

The model developed can be used for estimation, and when required, for revision of present dimensioning and design guidelines for vertical clarifiers. This presumes further calibration and verification of the model in regard to poorly settling sludges. Furthermore, the verification of influent sludge concentration must be complemented at higher concentrations than used in this investigation. Then, a simulation program can be planned and implemented, with which the load situations, relevant parameters, and their values selected for design, are tested.

Finally, the utilization of the model proposed here should be evaluated for the utilization of sludge thickening since the thickening of sludge blanket's lower part quite evidently describes the mechanism working in a sludge thickener. By complementing the model with mixers, chemical treatment, and other operations, it might be possible to improve the operation of the thickener.

\section{SUMMARY}

In the study, the effects of peak loading by rainfall and snowmelt waters on the operation of a vertical clarifier in an activated sludge wastewater treatment plant are evaluated.

The effects of flow variations in the influent quantity to the clarifier have been investigated using a full-scale vertical clarifier. The operation of the clarifier has been described by a dynamic simulation model, which can be used for establishing dimensioning and design criteria for vertical clarifiers. A new in-situ method for determining the sludge settling velocity is also introduced.

\section{Simulation model}

The sludge blanket movements in the lower part of the clarifier were formulated into a dynamic model in accordance with the method proposed by Tracy and Keinath (1973) by further taking into account the conical shape of the clarifier. Sludge thickening at the lower part of the clarifier and division into the its upper and lower parts is based on the solids flux theory. According to the flux theory, the part of the influent solids flow that reverts to the upper part of the blanket above the feed point, is that proportion of the influent solids flux entering the clarifier which exceeds the limiting solids flux of 
the flow directed downwards from the feed point.

As long as the sludge blanket surface is above the feed point, the upper part of the thickening model is based on the difference between the gravity influenced underflow and flow induced upward flow in the solids flux. The turbulent mixing caused by the upward flow around the settling sludge particles additionally reduces the settling velocity of the particle as shown below.

The concentration change in a time unit of a volume unit $\left(\mathrm{V}_{\mathrm{i}}\right)$ under study, that is the sludge accumulation or build-up, is equal to the difference between the inflow and outflow solids fluxes from which is then deducted the solids concentration difference caused by the turbulent mixing between the inflow and outflow (Fig. 6):

$$
\begin{aligned}
& v_{i} \frac{d C_{i}}{d t}=\left(w_{i-1} C_{i-1} A_{i-1}-w_{i} C_{i} A_{i+1}\right) \\
& +\left(v_{i+1} C_{i+1} A_{i+1}-v_{i} C_{i} A_{i-1}\right) \\
& -\left(A_{i-1 / 2} D_{i-1 / 2} \frac{C_{i-1}-C_{i}}{\Delta h}\right. \\
& \left.-A_{i+1 / 2} D_{i+1 / 2} \frac{C_{i}-C_{i+1}}{\Delta h}\right)
\end{aligned}
$$

$\mathrm{V}_{\mathrm{i}} \quad=$ layer $\mathrm{i}$ volume

$\mathrm{A}_{\mathrm{i}-1}=$ interface between layers $\mathrm{i}-1$ and $\mathrm{i}-2$

$A_{i+1}=$ interface between layers $i$ and $i+1$

$\mathrm{v}_{\mathrm{i}}=$ velocity due to gravity in layer $\mathrm{i}$

$\mathrm{w}_{\mathrm{i}}$ = liquid flow velocity in layer $\mathrm{i}$ due to withdrawal of clarified water

$\mathrm{C}_{\mathrm{i}}=$ solids concentration in layer $\mathrm{i}$

$\mathrm{D}=$ diffusion coefficient

$\Delta \mathrm{h}=$ layer thickness

\section{Experimental conditions and computational methods}

1. The final clarifier which was simulated by the model originally was a part of an activated-sludge wastewater treatment process complemented with simultaneous precipitation. Like the primary settling tank, the final clarifier of the experimental plant is a Dortmund well-type vertical settling tank with a diameter of $3.5 \mathrm{~m}$, depth of $3.6 \mathrm{~m}$, and volume of $16.8 \mathrm{~m}^{3}$. The inflow takes place at the center of the clarifier, and the effluent withdrawal from its periphery. Sludge accumulates by gravity and sludge recycle pumping takes place at the conical bottom of the tank.

The test conditions were designed to simulate flow variations caused by rainfall and snowmelt waters. The clarifier was loaded by pumping conventional domestic wastewater into it simulating a short pulse of peak load over 5 to 6 hours so that the flow was selected as $\mathrm{Q}_{\max }=$ approx. $20,25,30$ or $35 \mathrm{~m}^{3} \mathrm{~h}^{-1}$.

2. A new method was developed whereby the velocities were computed directly from concentration measurement results obtained from the clarifier when the process was operating in the equilibrium, or steady state. For the steady state of the process, in the equation used above is $\mathrm{V}_{\mathrm{i}}=\frac{\partial \mathrm{C}_{\mathrm{i}}}{\partial \mathrm{t}}=0$ allowing the sludge settling velocity to be solved.

3. In order to determine sludge settling velocity at different depths in the sludge blanket, the clarifier was horizontally divided into six layers. The inflow and outflow solids quantity of each layer in a time interval (between the measurements) was computed from the concentration changes measured.

\section{Results from test runs}

1. When load is changed in steps, the sludge concentration profile of the clarifier remains grossly unchanged. In each loading phase, the sludge blanket concentration above the feed pipe orifice level $(1.8 \mathrm{~m})$ is almost constant in the vertical direction. By contrast, sludge is thickened below the feed point level and concentration increases in relation to depth.

During the increased flow (time 08:30...11:30), solids concentration at different depths decreases from top to bottom, but the sludge blanket level raises, which indicates the accumulation of solids in the upper part of the clarifier. During the decreased flow (time 11:30..13:30), sludge is thickened in the clarifier while the sludge blanket level simultaneously sinks. The recycle flow during the test was $50 \%$ of the inflow to the treatment plant. When the recycle flow was increased (e.g. to $100 \%$ ), the concentration in the lower part of the sludge blanket was found to decrease to the concentration level of the second part.

2. Zone settling velocities have been measured from sludges of different ages (ages approx. $3 \mathrm{~d}$ and approx. $14 \mathrm{~d}$ ). During the test, temperature varied in the range of $11.6 \ldots 13.6^{\circ} \mathrm{C}$. Zone settling velocities obtained from sludges of higher age (approx. $14 \mathrm{~d}$ ) are significantly higher (approx. $1.0 \ldots 0.3 \mathrm{~m} \mathrm{~h}^{-1}$ within the concentration range of $2.5 \ldots 4.25 \mathrm{~g} \mathrm{l}^{-1}$ ) than results obtained from sludges of less age. With the increase of sludge concentration (above $5 \mathrm{~g} \mathrm{l}^{-1}$ ), the results show that the difference decreases to an insignificant level for practical applications. No statistically significant difference was obtained for zone settling velocities in tests where temperature differences fell within 
the range of $10 \ldots 12^{\circ} \mathrm{C}$.

The effect of sludge blanket depth to the sludge settling velocity within the blanket has been computed from the concentration measurement results. The results obtained were in the same order of magnitude as referred to in the literature. Thus, a depth increase of $0.5 \mathrm{~m}$ has increased the settling velocity by $0.3 \ldots 0.4 \mathrm{~m} \mathrm{~h}^{-1}$.

The velocities computed from the concentration measurement results with the help of equilibrium state of the clarifier sludge blanket were (e.g. in tests performed on Nov. 16...26, 1984) even as high as twofold compared to corresponding zone settling velocities obtained in calibration cylinder tests. Sludge concentration was then $2 . .4 \mathrm{~g} \mathrm{l}^{-1}$, which corresponded to sludge concentrations generally found in the upper part of the clarifier.

3. Doubling the hydraulic surface load relative to the dimensioning flow has, according to the tests, increased the effluent solids concentration by about $75 \%$, and a 2.5-fold dimensioning flow increased the concentration by about $150 \%$ compared with the dimensioning values.

\section{Calibration, verification and sensitivity of the model}

1. The model has been calibrated by determining the sludge velocity relevant to the moment of observations together with the dependence of velocity on the sludge blanket height. Calibration has been performed separately for successive runs and collected data as a whole.

2. The accuracy of verification results depends decisively on the sludge settling velocity used, which varies according to the sludge quality. The accuracy of verification runs for the collected data as a whole was, on the average, $23 \mathrm{~cm}$, and at the upper level of the sludge blanket $25 \mathrm{~cm}$. The precision of successive runs was clearly better. The corresponding figures are $11 \mathrm{~cm}$ and $3 \mathrm{~cm}$.

3. The sensitivity of the model structure was tested by altering the flow, its solids concentration, sludge recycling by $\pm 5 \%$ as well as the sludge settling velocity by $\pm 10 \%$, and then comparing the results to changes in sludge blanket level. Sensitivity changes as a function of time were found to be logical.

\section{Results obtained from the simulation model}

The model has been applied in the simulation of clarifier load changes in four different ways by separately altering each input parameter (flow, solids, sludge recycle ratio), and keeping the other parameters constant.
1. In the first simulation, a flow peak has been simulated with a decreasing solids concentration while keeping the solids load constant. Running the model at a constant sludge surface load but at an increased hydraulic surface load, the sludge blanket level decreased at an increased hydraulic surface load (Fig. 25). This is caused by solids concentration decrease in inflow and simultaneously in the clarifier sludge blanket, which further significantly increases sludge settling velocity. The increased sludge settling velocity by itself discernibly sinks the sludge blanket height.

2. In the second run, a flow peak has been simulated in which the solids concentration has been constant during load changes but inflow (that is, hydraulic surface load) has varied as described above. The growth of flow has increased the solids load (sludge surface load) in the same ratio. With an increasing load, the sludge blanket level has grown relative to the reference run while a decrease in the load has lowered the level.

3. In the third run, the influent solids concentration has been altered in relation to the reference run. Increase in influent concentration has increased the solids load (and consequently the sludge surface load), as well as the sludge blanket height in comparison to the reference run. Correspondingly, a decrease in the influent sludge concentration has decreased the sludge blanket height.

4. The fourth run simulates sludge recycle effect on the sludge blanket profile. Changes in sludge recycle have not noticeably influenced the sludge blanket level compared to the reference run. By contrast, the sludge blanket profile has become leaner, which indicates lessened solids concentration in the sludge blanket for increased recycling and, vice versa, a higher concentration for lower recycle ratios, respectively.

\section{Conclusions}

1. Consequently, in order to improve the accuracy of modelling, test runs should be performed in test series of several days under constant conditions in regards to the settling velocity. These test series should be run for different settling velocity conditions, such as different seasons of the year. After this, each test series with the same settling velocity should be calibrated separately.

2. Zone settling velocity does not offer satisfactory accuracy to be used for sludge settling approximation in clarifier modelling. Furthermore, the theory proposed by Kynch stating that settling velocity is only dependent on its concentration remains excessively inaccurate to be applied in the 
model. Factors affecting sludge settling velocity must also include particle size which has been approximated in this study by the sludge blanket thickness.

To conclude, in the developed model and in other models of similar dynamic character, the sludge settling velocity should be determined directly in the clarifier by taking into account velocity-related factors, such as sludge quality and sludge blanket thickness. This procedure is extensively facilitated by modern measurement equipment.

3. According to the results from the model, the efficiency and capacity of the clarifier depend mostly on the influent solids load to the clarifier, available sludge storage capacity, and sludge settling velocity in the clarifier. A low sludge concentration in effluent also decreases the solids concentration of the sludge blanket and increases the settling velocities of sludge and sludge blanket top level.

4. Model investigations on a vertical clarifier can be further improved by complementing the model with an aeration basin, which provides possibilities to evaluate, for instance, the interaction of aeration with clarification as well as the interdependence of different basin volumes. The in-situ method for determination of sludge settling velocity can also be improved. In order to simplify measurement and to speed computation of results, the model can be complemented with a supplementary program. Furthermore, extended analysis of sludge settling velocity finds an impetus, especially in conjunction with poorly settling sludges.

The model developed can be used for estimation, and when required, for revision of present dimensioning and design guidelines for vertical clarifiers. This presumes further calibration and verification of the model in regard to poorly settling sludges. Then, a simulation program can be planned and implemented, with which the load situations, relevant parameters, and their values selected for design, are tested.

\section{ACKNOWLEDGMENTS}

This study was performed at the Technical Research Office of the Water Research Institute (presently Water and Environment Research Insti-

tute). It has been financed by the National Board of Waters (presently National Board of Waters and Environment), the Maj and Tor Nessling Foundation, and the Sven Hallin Research Fund.

I would first like to thank Ms. Auli Niemi, M.Sc., for helping in the compilation of literature references. The experimental arrangements at the Suomenoja test plant were performed by Mr. Timo Laaksonen, Research Engineer. The analyses were run at the laboratories of the National Board of Waters.

Mr. Sakari Välimaa, M.Sc., and Mr. Markku Liponkoski, M.Sc., provided invaluable assistance in the practical realization of the investigations. Mr. Välimaa took care of the test arrangements and handling of test results while Mr. Liponkoski performed all computer operations.

The original Finnish manuscript was typed by Ms. Päivi Laaksonen with the help of Ms. Jaana Arpalahti-Kolu and typists Maritta Mäki and Lea Lind. Publications secretary, Ms. Terttu Halme helped in planning of the diagrams and graphs while Ms. Katriina Kytönen aided in their preparation. The final drawings were prepared by Ms. Paula Ullakko.

Mr. Matti Valve, Lic.Tech., proved indispensable through the course of the study with his advice on planning the study and processing test data. Mr. John Forsius, M.A., and Mr. Juhani Kettunen, M.Sc. assisted in development of the simulation model.

Finally, I express my deepest gratitude to Prof. Eero Kajosaari, Helsinki University of Technology, Faculty of Surveying and Civil Engineering, who reviewed the manuscript of the thesis and contributed valuable insights. Dr. Pentti Yletyinen and Dr. Jukka Ranta, who took the pain of prereviewing the study, contributed to essential improvements. Prof. Seppo Mustonen, Director of the Water Research Institute gave me encouragement to complete the study.

The English version was edited by Mr. Taisto Leinonen, typed and stylized by Ms. Lisa MacDowell-Lindfors, and checked by Mr. Greg Moore.

I would once again like to thank all the people and institutions who contributed their time and effort to making this study possible.

Helsinki, September 1987

Hannu Laikari 


\section{TIIVISTELMÄ}

Tutkimuksessa on arvioitu sade- ja sulamisvesistä muodostuvien kuormitushuippujen vaikutuksia aktiivilietepuhdistamon jälkiselkeyttimen toimintaan. Kuormitusvaihteluja on tutkittu täysimittakaavaisella pystyselkeyttimellä ja sitä varten on kehitetty dynaaminen simulointimalli. Mallilla on simuloitu kuormitusvaihteluista johtuvia lietepatjan profiilin muutoksia selkeyttimessä. Sillä voidaan tarkastella erikseen virtaaman, kiintoainekuormituksen ja liet- teenkierrätyksen vaikutuksia lieteprofiiliin ja selkeyttimen kapasiteettiin käyttämällä lietepatjassa erilaisia lietteen laskeutumisnopeuksia. Mallin avulla voidaan tarkistaa pystyselkeyttimen mitoitus- ja suunnitteluohjeita. Mallia varten on lisäksi kehitetty uusi lietteen laskeutumisnopeuden in situ -määritysmenetelmä, joka ottaa huomioon myös lietepatjan paksuuden vaikutuksen lietteen laskeutumisnopeuteen.

Tutkimus on julkaistu suomeksi sarjassa Vesi- ja ympäristöhallinnon julkaisuja n:o 10.

\section{LIST OF SYMBOLS}

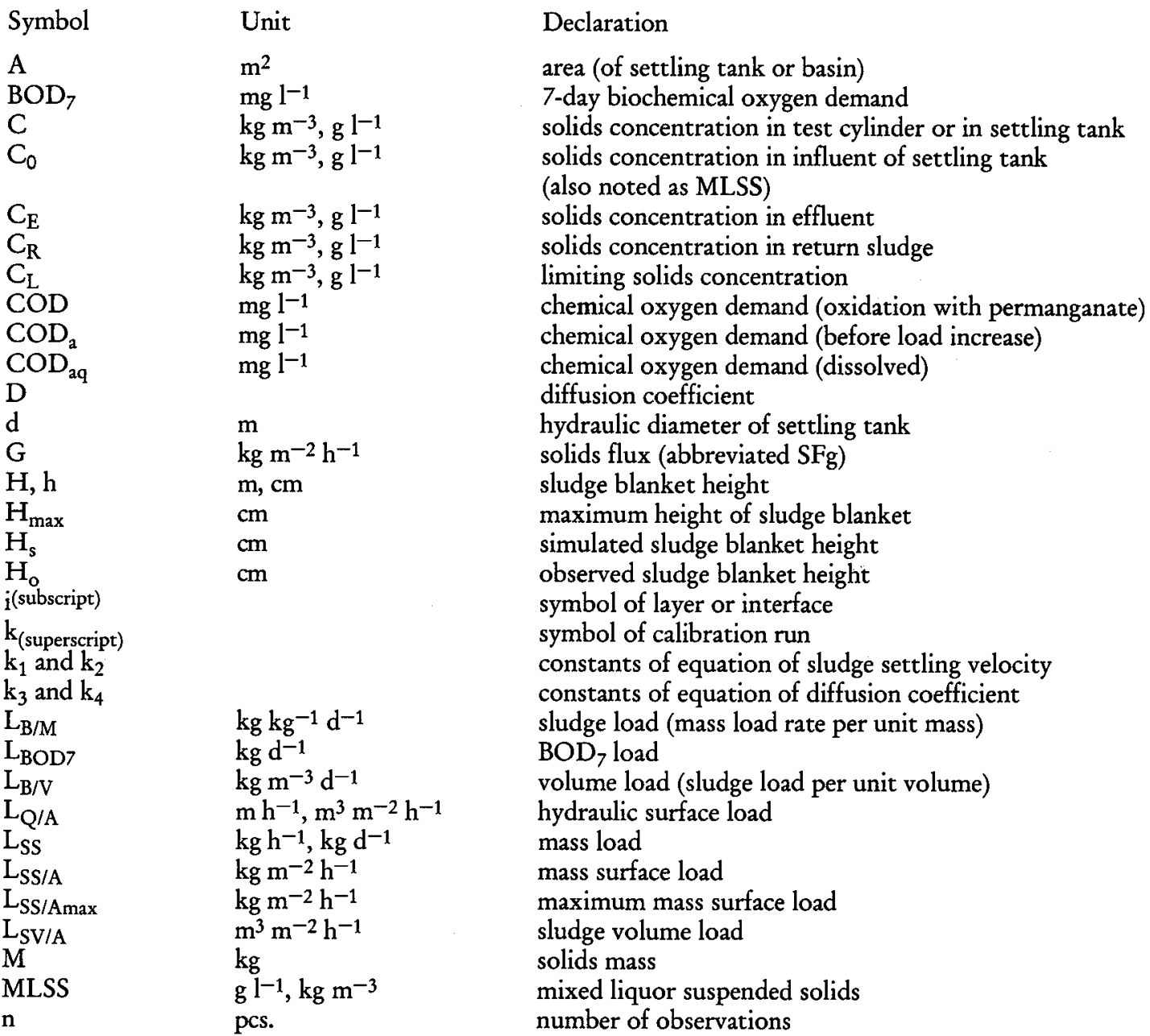




\begin{tabular}{|c|c|c|}
\hline$P_{\text {tot }}$ & mg $1^{-1}$ & total phosphorus \\
\hline$P_{\text {tota }}$ & $\mathrm{mg} \mathrm{l}^{-1}$ & total phosphorus before load increase \\
\hline$P_{\mathrm{aq}}$ & $\mathrm{mg} 1^{-1}$ & dissolved phosphorus \\
\hline $\mathrm{p}$ & $\mathrm{cm}$ & height of sludge blanket (parameter in sensitivity test) \\
\hline $\mathbf{R}$ & $\%$ & recycle ratio (of return sludge) \\
\hline Q & $m^{3} d^{-1}$ & influent flow \\
\hline Qo & $\mathrm{m}^{3} \mathrm{~h}^{-1}$ & inflow to settling tank \\
\hline $\mathrm{QE}_{\mathrm{E}}$ & $\mathrm{m}^{3} \mathrm{~h}^{-1}$ & effluent flow \\
\hline $\mathrm{Q}_{\mathrm{R}}$ & $\mathrm{m}^{3} \mathrm{~h}^{-1}$ & return sludge flow \\
\hline $\mathrm{QW}_{\mathrm{W}}$ & $\mathrm{m}^{3} \mathrm{~h}^{-1}$ & waste sludge flow \\
\hline$Q_{\text {dim }}$ & $\mathrm{m}^{3} \mathrm{~h}^{-1}$ & design flow \\
\hline $\mathrm{Q}_{\max }$ & $\mathrm{m}^{3} \mathrm{~h}^{-1}$ & maximum flow \\
\hline $\begin{array}{l}S \\
s\end{array}$ & & sensitivity (of model) \\
\hline SS & & standard deviation \\
\hline SS & $\mathrm{mg} \mathrm{^{-1 }}$ & solids concentration in effluent \\
\hline $\mathrm{SS}_{\mathrm{a}}$ & $\mathrm{mg} \mathrm{l}^{-1}$ & solids concentration in effluent before load increase \\
\hline $\mathrm{SS}_{\max }$ & $\mathrm{mg} \mathrm{l}^{-1}$ & maximum solids concentration \\
\hline SVI & $\mathrm{cm}^{3} \mathrm{~g}^{-1}$ & sludge volume index \\
\hline $\mathrm{T}$ & ${ }^{\circ} \mathrm{C}$ & temperature \\
\hline $\mathrm{t}$ & h, d & time \\
\hline$t_{d}$ & $\mathrm{~h}$ & detention time \\
\hline$t_{s}$ & $\mathrm{~d}$ & sludge age \\
\hline $\mathrm{u}$ & $\mathrm{mh}^{-1}$ & underflow velocity of sludge \\
\hline V & $\mathrm{m}^{3}$ & volume of settling tank or volume of layer \\
\hline $\mathbf{v}$ & $\mathrm{m} \mathrm{h}^{-1}$ & gravity induced velocity of sludge \\
\hline $\mathbf{v}_{\mathbf{L}}$ & $\mathrm{m} \mathrm{h}^{-1}$ & limiting velocity of sludge flow \\
\hline $\mathbf{v}_{s}$ & $\mathrm{~m} \mathrm{~h}^{-1}$ & zone settling velocity (hindered settling velocity) \\
\hline $\mathbf{w}$ & $\mathrm{m} \mathrm{h}^{-1}$ & flow velocity (upwards in settling tank, caused by $\mathrm{Q}_{\mathrm{E}}$ ) \\
\hline $\mathbf{x}$ & $\left(\mathrm{m}^{3} \mathrm{~h}^{-1}, \mathrm{~g} \mathrm{l}^{-1}\right)$ & parameter (flow or concentration in sensitivity test) \\
\hline$\overline{\mathbf{x}}$ & & arithmetic mean value \\
\hline
\end{tabular}

\section{REFERENCES}

Association of Finnish Cities. 1980. Design of a wastewater treatment plant. Publication B 87. p. 43. (Ref. National Board of Waters). (In Finnish.)

Bisogni, J.J. \& Lawrence, A.W. 1971. Relationships between biological solids retention time and settling characteristics of activated sludge. Water Research, vol. 5, p. 753 ...763.

Busby, J.B. \& Andrews, J.F. 1975. Dynamic modelling and control strategies for the activated sludge process. Journal WPCF, vol. 47, no. 5, p. 1055 ... 1080.

Chao, A.C. \& Keinath, T.M. 1979. Influence of process loading intensity on sludge clarification and thickening characteristics. Water Research, vol. 13, p. $1213 . .1223$.

Chobrial, F.H. 1978. Importance of the clarification phase in biological process control. Water Research, vol. 12, p. 1009 . . 1016.

Collins, C.E. et al. 1978. The effect of temperature

control on biological wastewater treatment process. Water Research, vol. 12, p. 547 ...554.

Dick, R.I. 1970. Role of activated sludge final settling task. Journal San. Eng. Division, vol. 96, no. 2, p. 423 ...436.

Dick, R.I. 1972. Sludge treatment. In: Weber, W. (ed.). Physico-chemical processes for water quality control. Wiley Interscience. New York. (Ref. Schroeder 1977.)

Dick, R.I. 1976. Folklore in the design of final settling tanks. Journal WPCF, vol. 48, no. 4, p. 633 ...644.

Dick, R.I. \& Eving, B.B. 1967. Evaluation of activated sludge thickening theories. Journal Sanit. Eng. Division, vol. 93, no. 4. (Ref. Metcalf \& Eddy, Inc. 1979.)

Gaydy, A.F. Jr. \& Gaydy, E.T. 1980. Microbiology for environmental scientists and engineers. McGraw-Hill Book Company, New York. 736 p.

Hernebring, C. 1984. Effects of temperature and flow variations on the activated sludge process. Lulea Technical University, Luleå. Preliminary report of literature and theoretical calculations no. 15. 25 p. (In 
Swedish.)

Keinath, T.M. et al. 1977. Activated sludge - unified system design and operation. Journal Env. Eng. Division, vol. 103 , no. 5 , p. 829.

Kynch, J.A. 1952. Theory of sedimentation. Trans. Faraday Soc., vol. 48, p. 166...167. (Ref. Tesarik and Vostril. 1970.)

Lockyear, C.F. 1978. Pilot-scale experiment on continuous gravity thickening of activated sludge. Water Research Centre. Technical Report TR 97, $25 \mathrm{p}$.

Metcalf \& Eddy, Inc. 1979. Wastewater engineering, treatment/disposal/reuse. Revised by G. Tchobanoglous. McGraw-Hill Book Co., New York. 920 p.

Munch, W.L. \& FitzPatrick. J.A. 1978. Performance of circular final clarifiers at an activated sludge plant. Journal WPCF, vol. 50, p. 265...276.

Mäkelä, M. 1981. The effect of temperature on the biological treatment process and its design. INSKO Report. Helsinki. 26 p. (In Finnish.)

National Board of Waters. 1976. Guidelines for design of municipal wastewater treatment plants. Helsinki. p. 18...23. Preliminary report II. (In Finnish.)

National Board of Waters. 1982. Guidelines for design of settling and aeration at municipal wastewater treatment plants. Mimeograph of NBW, no. 1982:134. Helsinki. 18 p. (In Finnish.)

National Board of Waters and Environment. 1987. Water supply and sewerage in Finland in 1986. Preliminary report of NBWE. (In Finnish.)

Olsson, G. 1987. Dynamic modelling, estimation and control of activated sludge systems. Beck, M.B. (ed.), System analysis in water quality management. Oxford, Pergamon Press. P. 349...356. Proceedings of a symposium held in London, U.K., 30 June-2 July, 1987. Published in the series Advances in water pollution control.

Pflanz, P. 1969. Performance of activated sludge secondary sedimentation basins. Adv. Wat. Pollut. Research. Perganom Press. New York. (Ref. Chobrial
1978, Roper and Grady 1974 and Collings et al. 1978.)

Roper, R.E. \& Grady, C.P.L. 1974. Activated sludge hydraulic-control techniques evaluation by computer simulation. Journal WPCF, vol. 46, no. 11, p. $2565 \ldots 2578$.

Shiba, A.M. and Inone, Y. 1975. Dynamic Response of Settling Basins. Journal Eng. Division, vol. 9, p. $741 \ldots 757$.

Särner, E. \& Marklund, S. 1981. Effect of snowmelt on the activated sludge process. Luleå, Luleå Technical University. 25 p. (In Swedish.)

Särner, E. \& Marklund, S. 1982. Effect of snowmelt on the activated sludge process. Vatten, no. 38, p. 17...33. (In Swedish.)

Talmadge, W.P. \& Fitch, E.B. 1955. Determining thickener unit areas. Ind. Eng. Chem., vol. 47, no. 1. (Ref. Metcalf \& Eddy, Inc. 1979.)

Task Committee on Final Clarification of the Water Pollution Management Committee. 1979. Final clarifiers for activated sludge plants. Journal Env. Eng. Division, vol. 105 , no. 5, p. $803 \ldots 817$.

Tesarik, I. \& Vostril, J. 1970. Hindered settling and thickening of chemically precipitated flocks. In: 5 th International Water Pollution Research Conference Proceedings. $7 \mathrm{p}$.

Tracy, K.D. \& Keinath, T.M. 1973. Dynamic model of activated sludge. Water, vol. 70 , no. 136, p. 291 ...308.

Vasiliev, V.B. \& Vavilin, V.A. 1982. Activated sludge system design for large variations of organic loading. Biotechnology and Bioengineering, vol. 24, p. 2337... 2355.

Water Association. 1986. Applied hydrology. Mänttä. p. 328... 329. (In Finnish.)

Wong, Y.K. \& Yang, P.Y. 1977. Effects of quantitative shock loadings on the constant recycle sludge concentration activated-sludge process. Biotechnology and Bioengineering, vol. 19, p. 43...53. 